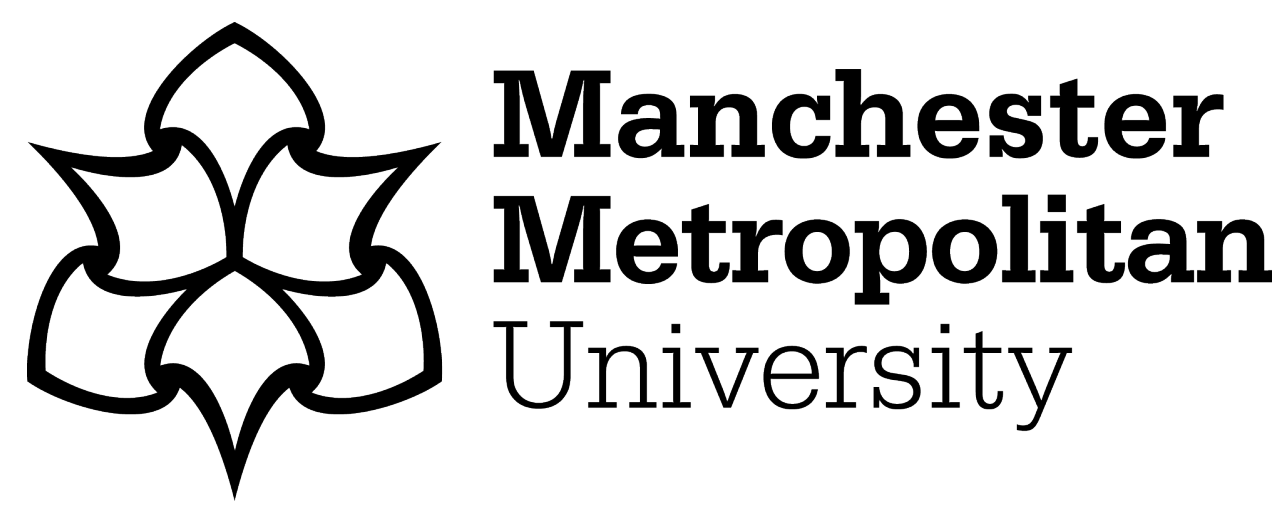

Kong, W, Huang, S, Shi, F, Zhou, JG, Feng, Y and Xiao, Y (2018) Study on Microcystis aeruginosa growth in incubator experiments by combination of Logistic and Monod functions. Algal Research, 35. pp. 602-612. ISSN 2211-9264

Downloaded from: https://e-space.mmu.ac.uk/621643/

Version: Accepted Version

Publisher: Elsevier

DOI: https://doi.org/10.1016/j.algal.2018.10.005

Usage rights: Creative Commons: Attribution-Noncommercial-No Derivative Works 4.0

Please cite the published version 


\title{
Study on Microcystis aeruginosa growth in incubator experiments by combination of Logistic and Monod functions
}

Wenwen Kong ${ }^{1}$, Suiliang Huang ${ }^{1 *}$, Feifei Shi ${ }^{1}$, Jianguo Zhou ${ }^{2}$, Yibei Feng ${ }^{1}$, Yao $\mathrm{Xiao}^{1}$

${ }^{1}$ Key Laboratory of Pollution Processes and Environmental Criteria of the Ministry of Education, Key Laboratory of Urban Ecological Environment Rehabilitation and Pollution Control of Tianjin, Numerical Simulation Group for Water Environment, College of Environmental Science and Engineering, Nankai University, Tianjin 300350, China

*Corresponding author. Email:slhuang@nankai.edu.cn. Tel:+13752342669

${ }^{2}$ School of Computing, Mathematics and Computation, Manchester Metropolitan University, Manchester M1 5GD, UK

\begin{abstract}
:
A combination of Logistic and Monod functions was proposed in this paper to study Microcystis aeruginosa growth in incubator experiments. This enables the Microcystis aeruginosa growth dynamics to be better described in incubator experiments and its parameters to be calculated more accurately. This method was verified by the data from the experiment and applied to study the effect of prometryn on Microcystis aeruginosa growth. In the experiment, a different concentrations of prometryn $(0,50$, 100 and $200 \mu \mathrm{g} \cdot \mathrm{L}^{-1}$ ) were added to the culture medium; the algal cell density, concentrations of orthophosphate $\left(\mathrm{PO}_{4}{ }^{3-}-\mathrm{P}\right)$ and ammonia nitrogen $\left(\mathrm{NH}_{4}{ }^{+}-\mathrm{N}\right)$ were measured. The results show that Microcystis aeruginosa growth with time can be well
\end{abstract}


described using the Logistic function. The maximum algae densities of Microcystis aeruginosa corresponding to the four prometryn concentrations are $11.7 \times 10^{6}, 8.1 \times 10^{6}$, $5.6 \times 10^{6}$ and $3.0 \times 10^{6}$ cells $\cdot \mathrm{mL}^{-1}$, respectively. The derived formula for the specific growth rate, growth rate and inhibition rate using Logistic function agreed reasonably well with the measured data. It was found that variations of consumed nutrients concentrations $\left(\mathrm{PO}_{4}{ }^{3-}-\mathrm{P}\right.$ and $\left.\mathrm{NH}_{4}{ }^{+}-\mathrm{N}\right)$ can also be well described by the Logistic function. A function that describes the relationship between algal densities and consumed nutrient $\left(\mathrm{PO}_{4}{ }^{3-}-\mathrm{P}\right.$ and $\left.\mathrm{NH}_{4}{ }^{+}-\mathrm{N}\right)$ concentrations is also derived from the Logistic function. Combination of Monod and Logistic functions can better describe relationship between specific growth rates and nutrients concentrations compared to the use of Monod function alone. In general, the half saturation coefficient, $K_{c}$ for $\mathrm{PO}_{4}{ }^{3-}-\mathrm{P}\left(4.74 \times 10^{-4}, 1.99 \times 10^{-3}, 5.54 \times 10^{-3}\right.$ and $\left.3.87 \times 10^{-2} \mathrm{mg} \cdot \mathrm{L}^{-1}\right)$ and $K_{c}$ for $\mathrm{NH}_{4}{ }^{+}-\mathrm{N}$ $\left(1.80 \times 10^{-3}, 5.84 \times 10^{-3}, 5.23 \times 10^{-3}\right.$ and $\left.1.06 \times 10^{-2} \mathrm{mg} \cdot \mathrm{L}^{-1}\right)$ in Monod function increase with increasing prometryn concentrations, which indicates that the affinity of algae growth to $\mathrm{PO}_{4}{ }^{3-}-\mathrm{P}$ and $\mathrm{NH}_{4}{ }^{+}-\mathrm{N}$ decrease with increasing prometryn concentrations. In addition, relationships between nutrients concentrations and time can be derived by combining of Monod with Logistic functions, which agree well with the measured data. It is concluded that the combined application of Monod and Logistic functions provides a promising and more robust method of studying algal growth in incubator experiments.

Key words: Logistic function; Monod function; Prometryn; Microcystis aeruginosa; Nutrients

\section{Introduction}

With the development of modern agriculture, the amount of herbicides used in agricultural production increases year after year, and herbicides exposed to the 
environment can enter water bodies though spray drift, soil leaching, rainfall erosion, surface runoff and so on (Sergio et al., 2013). Prometryn (CAS-No. 7287-19-6) is a persistent methylthiotriazine herbicide (Liebig et al., 2008) acting as a PSII inhibitor, which is frequently found in aquatic ecosystems mainly through terrestrial runoffs or land drainage. Prometryn in water are quite stable with long half-life time and difficult to degrade. It is toxic to higher plants, algae and a lesser extent to other non-photosynthetic organisms. Although prometryn has been banned in Europe since 2004 (Zhou et al., 2012), it is still being widely used in China (Zhou et al., 2012) and can be found in surface and groundwater. Xu et al. (2016) analyzed the concentrations of herbicide in surface water of major basins in China, and prometryn was detected in Taihu Lake, Yangtze River, Heilongjiang River, Songhuajiang River and the eastern and middle canals of the South-North Water Transfer Project. The average concentration in the aforementioned basins was $42.6 \mathrm{ng} \cdot \mathrm{L}^{-1}, 24.8 \mathrm{ng} \cdot \mathrm{L}^{-1}, 19.3 \mathrm{ng} \cdot \mathrm{L}^{-1}$, $18.9 \mathrm{ng} \cdot \mathrm{L}^{-1}$ and $16.4 \mathrm{ng} \cdot \mathrm{L}^{-1}$ respectively. Ma et al. $(2002 ; 2006)$ analyzed the toxicity of forty herbicides including prometryn and different kinds of green algae and found that different algae have different sensitivities to prometryn. In Wilkinson et al.'s (2015) study, effective photosynthetic quantum yield of Halophilaovalis exposing 11 $\mu \mathrm{g} \cdot \mathrm{L}^{-1}$ prometryn decreases by $50 \%$ during 24 hours, and in the study of Scenedesmus vacuolatus, effective photosynthetic quantum yield was reduced by $50 \%$ when the concentration of prometryn was $12.5 \mu \mathrm{g} \cdot \mathrm{L}^{-1}$ (Faust et al., 2001).

Worldwide, not only herbicides but also nutrients are common components of agricultural runoff (Murdock and Wetzel 2012). As well known, nutrients are necessary conditions for algal growth. Wu et al. (2012) believed orthophosphate phosphorus $\left(\mathrm{PO}_{4}{ }^{3-}-\mathrm{P}\right)$ and ammonia nitrogen $\left(\mathrm{NH}_{4}{ }^{+}-\mathrm{N}\right)$ were the most available form of phosphorus and nitrogen, respectively, which can be taken up by algae directly. 
The preference for ammonia nitrogen is considered to be due, at least in part, to lower energy requirements for the cell, and $\mathrm{NH}_{4}{ }^{+}-\mathrm{N}$ is more easily transported across the cell membrane than $\mathrm{NO}_{3}{ }^{-}-\mathrm{N}$ under balanced growth and $\mathrm{N}$ limited conditions (Glibert et al., 2015). García-Fernández and Diez (2004) summarized researches on the composition of nitrogen and carbon by Prochlorococcu and also found that forms of nitrogen Prochlorococcus used depended on the availability of different forms of nitrogen and the energy Prochlorococcus dissipated when utilizing nutrients.

Microcystis aeruginosa (M. aeruginosa) belonging to cyanobacteria is prokaryotic single-celled organism, which is often found in natural water bodies. It is widely used as a functioning organism in biological experiments (Chalifour et al., 2016). Over the past several years in China, M. aeruginosa has become one of the predominant species involved in water blooms around the entire country (Zhang et al., 2012). M. aeruginosa was used in Bittencourt-Oliveira's (2016) study to test the effect of saxitoxins on algae, and saxitoxins shows inhibition effect on M. aeruginosa. In Wu et al.'s study (2016), glyphosate concentrations of 2,5 and $10 \mathrm{mg} \cdot \mathrm{L}^{-1}$ also significantly inhibited the cell density production of M. aeruginosa.

To study microorganism growth, it is easier to apply kinetic models in controlling the microbial processes and predicting the behavior of the processes compared to laboratory experiments (Bailley and Ollos, 1986; Surendhiran et al., 2015). In the past, many mathematical models were proposed for microalgal growth, e.g., Logistic function (Goudar et al., 2005; Banks et al., 2012; Slegers et al., 2015; Surendhiran et al., 2015; Khalseh, 2016; Stemkovski et al., 2016; Samkhaniyani et al., 2017), Monod function (Khalseh, 2016; Huang et al., 2015) and many others (Zwietering, et al., 1990; Lemesle, 2008; Khalseh, 2016; Stemkovski et al., 2016). Logistic function describes the dynamics of population that are affected by 
density-dependence (Goudar et al., 2005), and it is used for a variety of unitary species of algae (Goudar et al., 2005; Wang et al., 2011; Surendhiran et al., 2015). However, Logistic function describes only the number of organisms without the consumption of substrate (Zwietering et al., 1990; Surendhiran et al., 2015). Monod function considers both the biomass and the rate limiting substrate concentrations in growth rate expression and is the most widely used kinetic equation for batch microbial growth (Monod 1949; Kayombo et al., 2003; Kargi 2009). Kargi (2009) believed Monod function is mechanistic with meaningful constants, and Logistic function is a mathematical approximation with a rather meaningless rate constant. Thus, both Logistic and Monod functions were considered to describe algal growth in the present study.

In light of the above background, prometryn and M. aeruginosa are selected as target herbicide and algae respectively to validate models for algae growth in the absence and presence of prometryn. In the present study, an indoor batch experiment under semi-controlled environmental conditions is carried out to study the effects of immediate exposure of prometryn on the growth process of $M$. aeruginosa, and to test whether and how Monod and Logistic Functions can be used to describe experimental data.

\section{Materials and Methods}

\subsection{Experimental materials}

Microcystis aeruginosa was obtained from the Freshwater Algae Culture Collection of the Institution of Hydrobiology (FACHB-905), Chinese Academy of Sciences. The algae were cultivated in an illumination. Prometryn $\left[\mathrm{C}_{10} \mathrm{H}_{19} \mathrm{~N}_{5} \mathrm{~S}, 2\right.$, 4-bis (isopropylamino)-6-(methyl-thio)-s-triazine] (purity $\geqslant 99 \%$ ) was purchased from 
Shanghai Aladdin Biochemical Technology Company Limited. Stock solution of prometryn was prepared by distilled water and the concentration was $33 \mathrm{mg} \cdot \mathrm{L}^{-1}$.

\subsection{Algal cultures}

Before the experiment, the algae M. aeruginosa was cultured in M-II culture medium for 15 days. The M-II culture medium was prepared in deionized water with $100 \mathrm{mg} \cdot \mathrm{L}^{-1} \quad \mathrm{NaNO}_{3}, \quad 10 \mathrm{mg} \cdot \mathrm{L}^{-1} \quad \mathrm{~K}_{2} \mathrm{HPO}_{4}, 75 \mathrm{mg} \cdot \mathrm{L}^{-1} \quad \mathrm{MgSO}_{4} \times 7 \mathrm{H}_{2} \mathrm{O}, 40 \mathrm{mg} \cdot \mathrm{L}^{-1}$ $\mathrm{CaCl}_{2} \times 2 \mathrm{H}_{2} \mathrm{O}, \quad 20 \mathrm{mg} \cdot \mathrm{L}^{-1} \quad \mathrm{Na}_{2} \mathrm{CO}_{3}, \quad 6 \quad \mathrm{mg} \cdot \mathrm{L}^{-1} \quad \mathrm{Fe} \cdot$ citrate $\times \mathrm{H}_{2} \mathrm{O}$ and $1 \mathrm{mg} \cdot \mathrm{L}^{-1}$ $\mathrm{Na}_{2} \mathrm{EDTA} \times 2 \mathrm{H}_{2} \mathrm{O}$. The initial $\mathrm{pH}$ value was adjusted to approximately 8.0 with 0.5 $\mathrm{mol} \cdot \mathrm{L}^{-1} \mathrm{HCl}$ and $0.5 \mathrm{~mol} \cdot \mathrm{L}^{-1} \mathrm{NaOH}$. The operational temperature and light intensity were $28^{\circ} \mathrm{C}$ and $3000 \mathrm{~lx}$ respectively, for the experiment undertaken in the case of illumination. In comparison, the corresponding values for the dark period were $20^{\circ} \mathrm{C}$ and $0 \mathrm{~lx}$. The cycle of light and darkness comprised $12 \mathrm{~h}$ of illumination and $12 \mathrm{~h}$ of darkness.

The medium containing algae was collected and then centrifuged for $15 \mathrm{~min}$ at a speed of $3000 \mathrm{r} \cdot \mathrm{min}^{-1}$. After removal of the supernatant, the algae were rinsed with 15 $\mathrm{mg} \cdot \mathrm{L}^{-1} \mathrm{NaHCO}_{3}$ solution and then centrifuged. After repeating the above procedure, the algae obtained via this procedure were cultured in M-II medium without nitrogen or phosphorus. Three days later, the algae would deplete the intracellular polyphosphate stores (Wu et al. 2012).

\subsection{Microcystis aeruginosa growth with prometryn addition}

Algae growth characteristics in prometryn media were assessed using batch incubation experiments. The flasks named CK with culture medium and without inoculating algae were used as the control groups. The algae were inoculated in the 
flasks named M0, M50, M100, M200 containing the same media as those in CK. To test the effect of prometryn on M. aeruginosa, low and high concentrations of 0,50 , 100 , and $200 \mu \mathrm{g} \cdot \mathrm{L}^{-1}$ of prometryn solution were added to M0, M50, M100 and M200 respectively. Duplicates were prepared. Flasks were shaken and their positions were randomly changed for three times a day. The initial algae density was $5.0 \times 10^{4}$ cells $\cdot \mathrm{mL}^{-1}$.

Experiments lasted for 43 days, during which algal cell density was counted every two days using a haemacytometer and a microscope (Vörös and Padisák, 1991). Counting was performed three times per sample. Water sampling started 1 day after algae addition, and $\mathrm{PO}_{4}{ }^{3-}-\mathrm{P}$ and $\mathrm{NH}_{4}{ }^{+}-\mathrm{N}$ were also measured every two days. We did not shake the samples before sampling. $\mathrm{NH}_{4}{ }^{+}-\mathrm{N}$ was analyzed using the phenol-hypochlorite method (Wetzel and Likens, 2000). Total nitrogen was analyzed using the method of alkaline potassium persulfate digestion with ultra-violet light spectroscopy. Concentrations of $\mathrm{PO}_{4}{ }^{3-}-\mathrm{P}$ and $\mathrm{TP}$ were determined via the persulphate digestion and ammonium molybdate spectrophotometric method (Wetzel and Likens, 2000)

\subsection{Statistical Analysis}

In this study, several models were examined for their applicability to the experimental data, using Origin 8.6 or SPSS 19.0 to determine the correlation coefficients between the measured and predicted variables.

\section{Theoretical background}

In this section, equations based on Logistic function for the growth rate, inhabitation rate and specific growth rate are formulated. Logistic function for the 
consumed nutrients concentrations and combination of Logistic and Monod functions that describe algaes growth are introduced, and equations for demarcation times of algae growth process are thus determined.

\subsection{Usage of Logistic function}

It has been well documented that algal growth can be described by Logistic function as shown in Eq. (1) (Goudar et al, 2005; Li et al., 2010; Wang et al., 2011; Qiao and Yu, 2014; Surendhiran et al., 2015, Khalseh, 2016).

$$
N=\frac{N_{\max }}{1+e^{a-r t}}
$$

where $N\left(1 \times 10^{4}\right.$ cells $\left.\cdot \mathrm{mL}^{-1}\right)$ is the algae density at any time, $N_{\max }$ is the maximum algae density $\left(1 \times 10^{4}\right.$ cells $\left.\cdot \mathrm{mL}^{-1}\right), r\left(\mathrm{~d}^{-1}\right)$ is the intrinsic growth rate, $t(\mathrm{~d})$ is time and $a$ (-) is a constant. $N_{\max }, a$ and $r$ can be obtained by fitting Eq. (1) to experimental data, as shown in Table 1 . The time, $t_{p}=a / r$ (day, at which $N=N_{\max } / 2$ ) is defined to set the second order derivative of Logistic function equal to zero, namely the inflection point of the growth curve.

Generation time $\left(G=\frac{\ln 2}{r}\right.$, day) represents the time which an algal cell takes to divide into two cells, and it is an important feature that characterizes the process of algae growth. However, in our experiments algae division was not synchronized. Instead, the average generation time was calculated (Powell, 1956; Reynolds, 1984).

In addition, to validate Logistic function (and Monod function) fitting the experiments, error $(E)$, relative error $(R E)$ and root mean square error (RMSE) (Huang et al., 2015) between fitted values and measured ones are calculated. The error is defined the differences between measured algal cell densities and fitted algal cell densities by logistic function (or measured specific growth rates and fitted specific 
growth rates by Monod function alone, or computed specific growth rates by Logistic function and fitted specific growth rates by a combination of Logistic and Monod functions).

According to Logistic function, the growth rate can be expressed as follows:

$$
\mu_{c}^{\prime}=\frac{d \mathrm{~N}}{d t}=\frac{N_{\max } r e^{a-r t}}{\left(1+e^{a-r t}\right)^{2}}
$$

where $\mu_{c}^{\prime}\left(1 \times 10^{4}\right.$ cells $\left.\cdot \mathrm{mL} \cdot \mathrm{d}^{-1}\right)$ is the computed growth rate. The growth rate reached its maximal value $\mu_{c \max }^{\prime}=r N_{\max } / 4\left(1 \times 10^{4}\right.$ cells $\left.\cdot(\mathrm{mL} \cdot \mathrm{d})^{-1}\right)$ as shown in Table 1 , where $N$ equals half of $N_{\max }$ (Li et al., 2010; Qiao and Yu, 2014).

The formula of the specific growth rate based on Logistic function is

$$
\mu_{c}=\frac{d(\ln N)}{d(t)}=\frac{r e^{a-r t}}{1+e^{a-r t}}
$$

in which $\mu_{c}\left(\mathrm{~d}^{-1}\right)$ is the computed specific growth rate.

Inhibition rate is defined as the ratio of the difference between algae densities in groups without and with prometryn to the algae density in the group without prometryn. It is used to describe the inhibition effect of chemical on algae growth. According to Logistic equation, the inhibition rate can be determined by

$$
I=\left[1-\frac{N_{\max -n}\left(1+e^{a_{0}-r_{0} t}\right)}{N_{\max -0}\left(1+e^{a_{n}-r_{n} t}\right)}\right] \times 100 \%
$$

where $I(\%)$ is the inhibition rate, $N_{\max -n}\left(1 \times 10^{4}\right.$ cells $\left.\cdot \mathrm{mL}^{-1}\right), a_{n}(-)$ and $r_{n}\left(\mathrm{~d}^{-1}\right)$ represents $N_{\max }, a$ and $r$ of experimental groups with prometryn (M50, M100 and $\mathrm{M} 200)$ in Logistic equation, and $N_{\max -0}\left(1 \times 10^{4}\right.$ cells $\left.\cdot \mathrm{mL}^{-1}\right), a_{0}(-)$ and $r_{0}\left(\mathrm{~d}^{-1}\right)$ represents $N_{\max }, a$ and $r$ of the experimental group without prometryn (M0) in Logistic equation.

The percentage inhibition of the specific growth rate for each treatment replicate is calculated as (Rial et al., 2013; Zhang et al., 2014; Wang et al., 2013) 


$$
I^{\prime}=\frac{\mu_{0}-\mu_{a}}{\mu_{0}} \times 100 \%
$$

where $I^{\prime}$ is the percentage inhibition as shown in Table $1, \mu_{a}\left(\mathrm{~d}^{-1}\right)$ is the average specific growth rates in groups with prometryn from beginning to end, and $\mu_{0}\left(\mathrm{~d}^{-1}\right)$ is the average specific growth rate in M0 group from the beginning to the end.

As a powerful analytical tool, Logistic function can further be used to simulate nutrients consumption curves versus incubation time (Goudar et al., 2005). It can provide the most accurate information about nutrients reduction through the following formula:

$$
\Delta C=\frac{\Delta C_{\max }}{1+e^{a} \Delta C^{-r} \Delta C^{t}}
$$

where $t$ is the incubation time (d), $\Delta C$ is the consumed nutrient concentration (difference of nutrients concentrations between groups without and with algae) at time $t\left(\mathrm{mg} \cdot \mathrm{L}^{-1}\right), \Delta C_{\max }$ is the maximum consumed nutrient concentration, $r_{\Delta C}$ is the consumed rate constant $\left(\mathrm{d}^{-1}\right)$ and $a_{\Delta C}$ is a constant.

According to Eqs. (1) and (5), the formula of algae density based on consumed nutrient concentrations can be written as

$$
N=\frac{N_{\max }}{1+e^{a-r\left(a_{\Delta c}-\ln \left(\Delta C_{\max }-\Delta C\right)+\ln \Delta C\right) / r_{\Delta c}}}
$$

in which fitted values of $N_{\max }, a$ and $r$ are shown in Table 1 , and fitted values of $\Delta C_{\max }, a_{\triangle C}$ and $r_{\triangle C}$ are shown in Table 2. It should be pointed out that $N$ cannot be calculated by Eq. (6) when $\Delta C_{\max }$ is lower than $\Delta C$, and this is possible because $\Delta C_{\max }$ is a fitted value.

Empirical equations are used to describe the relationships between algal densities and nutrient utilization in Wu et al.'s study (2012). In their study, the following power equation was chosen from several empirical equations including linear function, exponential function and quadratic function and tested against the relationship between $M$. aeruginosa densities and consumed nutrient concentrations. 


$$
N=a \times \Delta C^{b}
$$

where $N\left(1 \times 10^{4}\right.$ cells $\left.\cdot \mathrm{mL}^{-1}\right)$ is the algae density, and $\Delta C\left(\mathrm{mg} \cdot \mathrm{L}^{-1}\right)$ is the consumed nutrients concentration.

\subsection{Description of Monod function}

Monod (1949) found that in continuous reactor systems with pure cultures, the relationship between the bacterial growth and the substrate availability in the system with a single growth-limiting substrate could empirically be expressed as Eq. (8), which is named Monod function. In the follow-up studies, Monod function is also used to describe the relationship between algal specific growth rates and nutrient concentrations (Healey 1980; Sunda et al., 2009; Cerucci et al., 2010; Xu et al. 2015; Lee et al., 2015; Zeng et al., 2016), which is an important ecological process in aquatic system (Cerucci et al., 2010).

$$
\mu=\frac{d N}{N d \mathrm{t}}=\frac{\mu_{m} C}{K_{c}+C}
$$

where $C$ is the rate-limiting nutrients concentration $\left(\mathrm{mg} \cdot \mathrm{L}^{-1}\right), \mu$ and $\mu_{m}$ are the specific growth rate $\left(\mathrm{d}^{-1}\right)$ and the maximum specific growth rate $\left(\mathrm{d}^{-1}\right)$ respectively, $K_{c}$ is the half saturation coefficient $\left(\mathrm{mg} \cdot \mathrm{L}^{-1}\right)$, as shown in Table 3.

\subsection{Algae growth with a combination of Logistic and Monod functions}

Actually, the specific growth rate could be computed by fitted Logistic function. Combining Monod function with Logistic function yields

$$
\frac{r e^{a-r t}}{1+e^{a-r t}}=\left(\mu_{c}=\right) \frac{\mu_{m} C}{K_{c}+C}
$$

By fitting the data sets of computed specific growth rates to measured nutrients concentrations, the parameters $\mu_{m}$ and $K_{c}$ in Monod function can be determined as shown in Table 3 and Fig.10. According to Eq. (1) and Eq. (9), $\mathrm{PO}_{4}{ }^{3-}-\mathrm{P}$ and $\mathrm{NH}_{4}{ }^{+}-\mathrm{N}$ 
concentrations can be described by Eq. (10).

$$
C=\frac{K_{c} \mu}{\mu_{m}-\mu}=K_{c} \frac{r e^{a-r t}}{\mu_{m}+\left(\mu_{m}-r\right) e^{a-r t}}
$$

in which values of $K_{c}$ and $\mu_{m}$ are given in Table 3, and values of $a$ and $r$ are provided in Table 1.

\subsection{Calculation of demarcation points}

It is well known that the algal growth can be divided into four phases generally: lag phase, exponential phase, stationary phase and decline phase. In the past, demarcation points (times) of algal growth phases are determined subjectively by observing algal growth curves. Actually, from Eq. (2), the first, second and third order derivatives of the growth rate could be continuously deduced. It can be found that there are three extremums for the second order derivative of the growth rate (as shown in Fig.11). Setting the third order derivative of the growth rate to zero, the three corresponding times, $t_{1}, t_{2}\left(=t_{p}\right)$ and $t_{3}$, to the three extremums of the second order derivative of the growth rate can be obtained as shown as follows

$$
\begin{aligned}
& t_{1}=\frac{a-\ln (5+2 \sqrt{6})}{r} \\
& t_{3}=\frac{a-\ln (5-2 \sqrt{6})}{r}
\end{aligned}
$$

\section{Results and Discussion}

\subsection{Experimental results}

From Fig.1a, it is obvious that our experiments captured three phases of $M$. aeruginosa growth: lag phase, exponential phase and stationary phase. At the beginning of the experiment, algal cell densities increase very slowly. As time goes, especially after the lag phase, M. aeruginosa gradually adapted to its new 
environment and recovered, and algal cell densities increased very fast, especially in the exponential phase. As shown in Fig.1a, algal cell densities in different groups decrease with increasing concentrations of prometryn, even in the lag phase. What's more, the time required for the recovery of $M$. aeruginosa growth increases with increasing prometryn concentrations. Although the immediate exposure of $M$. aeruginosa to prometryn affects its own growth, addition of $50 \sim 200 \mu \mathrm{g} \cdot \mathrm{L}^{-1}$ prometryn cannot completely prevent $M$. aeruginosa from growth, which means that $M$. aeruginosa has some tolerance to prometryn. Significance analysis indicates that prometryn has a significant inhibitory effect on $M$. aeruginosa growth when prometryn concentrations are $100 \sim 200 \mu \mathrm{g} \cdot \mathrm{L}^{-1}(p<0.05)$, while $50 \mu \mathrm{g} \cdot \mathrm{L}^{-1}$ concentration of prometryn has little effect $(p>0.05)$. Algae responses to contaminants vary widely depending mainly on their species and contaminant concentrations (Mhadhbi et al., 2012). This agrees on Jin et al.'s (2012) study that low concentrations (2.5 and 5.0 $\left.\mu \mathrm{g} \cdot \mathrm{L}^{-1}\right)$ of prometryn do not affect Chlamydomonas reinhardtii growth, while Chlamydomonas reinhardtii growth is inhibited when the prometryn concentrations are $7.5 \sim 12.5 \mu \mathrm{g} \cdot \mathrm{L}^{-1}$

$\mathrm{PO}_{4}{ }^{3-}-\mathrm{P}$ and $\mathrm{NH}_{4}{ }^{+}-\mathrm{N}$ is often the dominant phosphorus and nitrogen source utilized by phytoplankton (Harrison et al. 1996, Wu et al., 2012). Variations of $\mathrm{PO}_{4}{ }^{3-}-\mathrm{P}$ and $\mathrm{NH}_{4}{ }^{+}-\mathrm{N}$ with time are shown in Fig. $1 \mathrm{~b}$ and c. It can be seen from the figure that in the CK group (without algae), $\mathrm{PO}_{4}{ }^{3-}-\mathrm{P}$ and $\mathrm{NH}_{4}{ }^{+}-\mathrm{N}$ concentrations tend to be stable for the whole experiments although some fluctuations are noticed. In groups with algae, both $\mathrm{PO}_{4}{ }^{3-}-\mathrm{P}$ and $\mathrm{NH}_{4}{ }^{+}-\mathrm{N}$ concentrations decrease gradually until they are close to the detection level because they are uptaked and utilized by M. aeruginosa (Fig.1). $\mathrm{PO}_{4}{ }^{3-}-\mathrm{P}$ and $\mathrm{NH}_{4}{ }^{+}-\mathrm{N}$ concentrations in different groups are ranked as follows: $\mathrm{CK}>\mathrm{M} 200>\mathrm{M} 100>\mathrm{M} 50>\mathrm{M} 0$. This implies that the lower the density of algae, the 
higher the concentration of nutrients in water. Variations of $\mathrm{PO}_{4}{ }^{3-}-\mathrm{P}$ and $\mathrm{NH}_{4}{ }^{+}-\mathrm{N}$ concentrations with time in the present experiment are similar to those of Qiao and $\mathrm{Yu}$ (2014). It must be pointed out that we did not add any ammonia to the culture medium in the experiment but we did detect the existence of ammonia as shown in Fig. $1 \mathrm{~b}$ and c. This is because the commercial medium contains some ammonia.
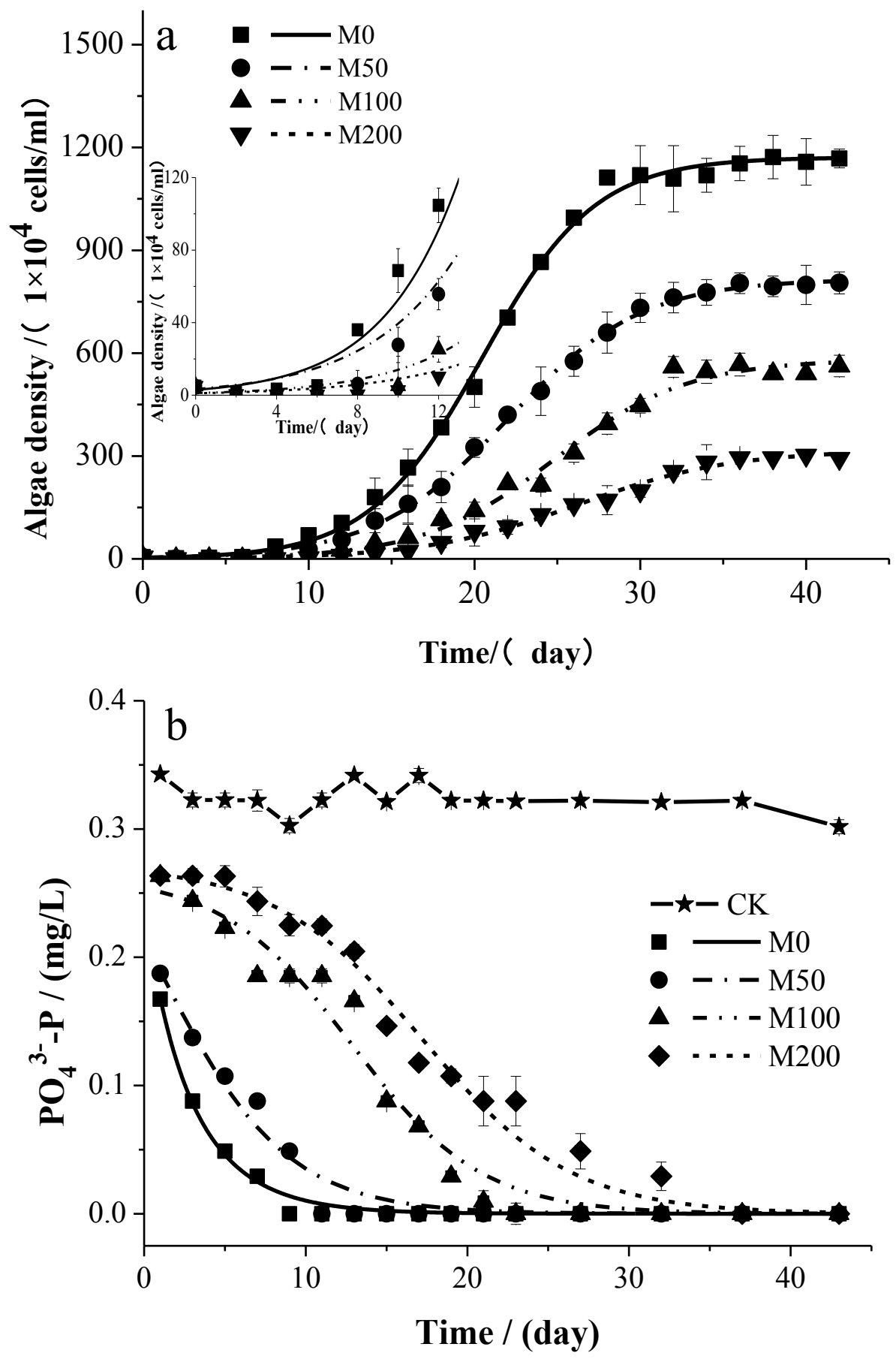


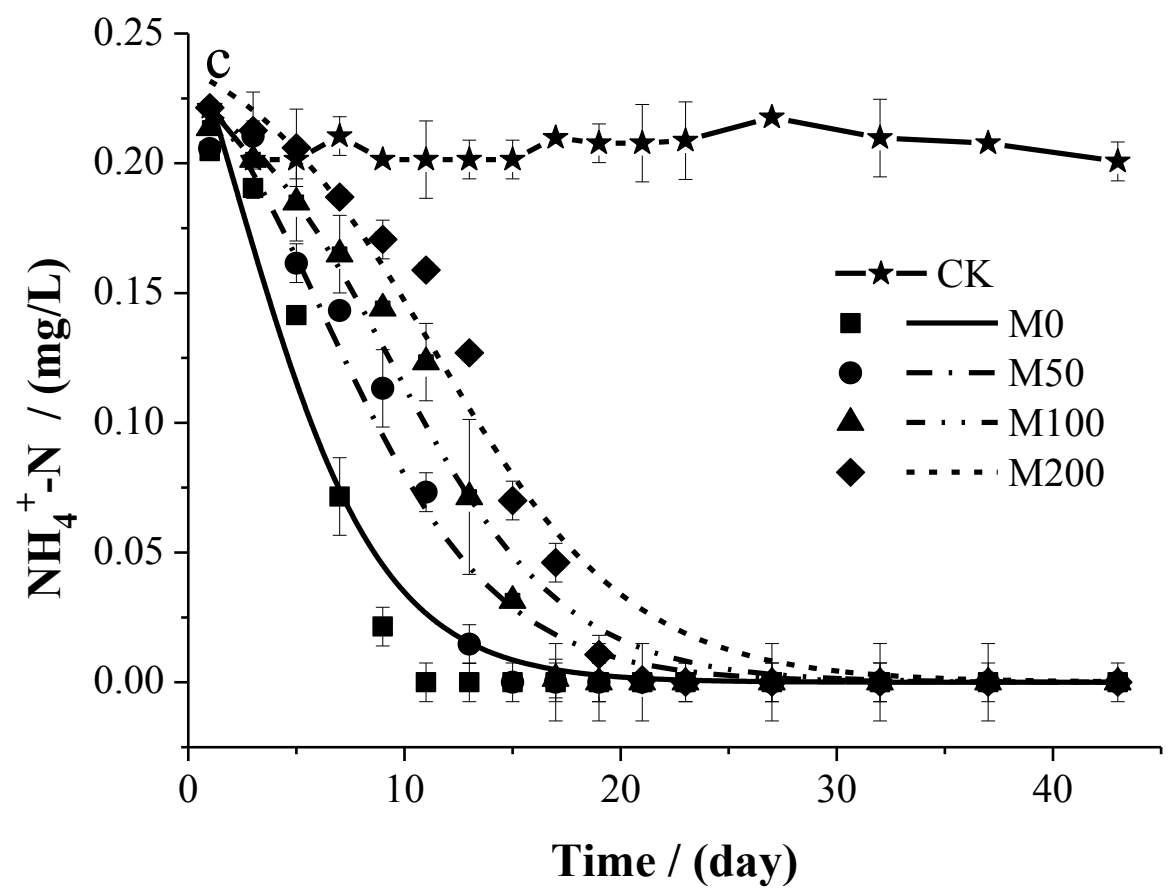

Fig.1 Variations of a) M. aeruginosa densities, b) $\mathrm{PO}_{4}{ }^{3-}-\mathrm{P}$ concentrations and c) $\mathrm{NH}_{4}{ }^{+}-\mathrm{N}$ concentrations with time $\left(\mathrm{CK}\right.$, culture medium; $\mathrm{M} 0,0 \mu \mathrm{g} \cdot \mathrm{L}^{-1}$ prometryn; M50, $50 \mu \mathrm{g} \cdot \mathrm{L}^{-1}$ prometryn; M100, $100 \mu \mathrm{g} \cdot \mathrm{L}^{-1}$ prometryn; M200, $200 \mu \mathrm{g} \cdot \mathrm{L}^{-1}$ prometryn. dots: measured values; lines: computed values) Data shown is the mean \pm SD of two independent measurements.

\subsection{Application of Logistic function alone}

\subsubsection{Growth curves of $M$. aeruginosa by Logistic function}

In our study, Fig.1a and Table 1 show that logistic function can describe the growth of $M$. aeruginosa with good accuracy $\left(R^{2}=0.990 \sim 0.999\right)$, and this is in agreement on the reported results (Surendhiran et al., 2015; Samkhaniyani et al., 2017). Kooijman et al. (1983) found that the effect of a toxic agent on microalgal growth is manifested by the maximum biomass and growth rate in the growth curve. Table 1 lists parameters of $N_{\max }$ and $r$ for M0, M50, M100 and M200, and both decrease with increasing concentrations of prometryn, which indicates that the inhibitory effect of prometryn on algae growth increase with increasing prometryn 
concentrations. In addition, $t_{p}$ and $G$ increase with the increase of prometryn concentrations, and this also conforms to inhibition effect of prometryn.

Table 1 Parameters of Logistic function describing algal growth

\begin{tabular}{ccccc}
\hline Parameter & M0 & M50 & M100 & M200 \\
\hline $\mathrm{a}$ & 5.980 & 5.460 & 6.196 & 5.707 \\
$r\left(\mathrm{~d}^{-1}\right)$ & 0.292 & 0.249 & 0.248 & 0.218 \\
$N_{\max }\left(1 \times 10^{4} \mathrm{cells} \cdot \mathrm{mL}^{-1}\right)$ & 1171.038 & 815.840 & 581.224 & 316.433 \\
$R^{2}$ & 0.998 & 0.999 & 0.990 & 0.993 \\
$t_{p}(\mathrm{~d})$ & 20 & 21 & 24 & 26 \\
$G(\mathrm{~d})$ & 2.374 & 2.784 & 2.795 & 3.180 \\
$\mu_{\text {cmax }}^{\prime}\left(1 \times 10^{4}\right.$ & & & & \\
cells $\left.^{2}(\mathrm{~mL} \cdot \mathrm{d})^{-1}\right)$ & 85.486 & 50.786 & 36.036 & 17.246 \\
$I^{\prime}(\%)$ & - & 6.8 & 13.4 & 25.4 \\
$E\left(1 \times 10^{4} \mathrm{cells} \cdot \mathrm{mL}^{-1}\right)$ & $-43.35 \sim 58.19$ & $-22.17 \sim 13.14$ & $-40.38 \sim 65.36$ & $-22.35 \sim 14.24$ \\
$R E$ & $0.00084 \sim 2.21$ & $0.00047 \sim 19.68$ & $0.00040 \sim 24.99$ & $0.0013 \sim 18.35$ \\
$R M S E\left(1 \times 10^{4} \mathrm{cells} \cdot \mathrm{mL}^{-1}\right)$ & 20.576 & 11.715 & 21.858 & 9.372 \\
\hline
\end{tabular}

$a$ : a constant; $r$ : the intrinsic growth rate; $N_{\max }$ : the maximum algae density; $R^{2}$ : correlation coefficient; $t_{p}$ : the inflection point of the growth curve; $G$ : Generation time; $\mu_{c m a x}^{\prime}$ : the maximal growth rate; $I^{\prime}$ : percentage inhibition; $E$ : Error; $R E$ : Relative error; RMSE: root mean square error. Data were calculated according to corresponding equations.

As shown in Table 1, Errors are quite small, and they are generally the smallest in lag phase $\left(-14.44 \sim 26.5710^{4}\right.$ cells $\left.\cdot \mathrm{mL}^{-1}\right)$ among those in exponential phase $\left(-43.35 \sim 65.3610^{4}\right.$ cells $\left.\cdot \mathrm{mL}^{-1}\right)$ and stationary phase $\left(-30.32 \sim 21.0010^{4}\right.$ cells $\left.\cdot \mathrm{mL}^{-1}\right)$. However, relative errors in lag phase $(0.10 \sim 24.99)$ are the highest among those in exponential $(0.01 \sim 0.41)$ and stationary phase $(0.00 \sim 0.051)$. Therefore, analysis of the errors and relative errors also indicates that Logistic function can be used to fit the experimental data well. It is also noted that when algal cell densities are low in lag phase, the relative errors are comparatively quite large. In Table 1, values of RMSE are $9.372 \sim 21.85810^{4}$ cells $\cdot \mathrm{mL}^{-1}$, respectively, corresponding to $1.4 \% \sim 3.7 \%$ of $N_{\max }$.

\subsubsection{Application of Logistic function to compute growth rates of $M$. aeruginosa}


The measured and computed growth rates are displayed in Fig.2a. As shown in the figure, the computed growth rates agree reasonably well on measured ones with $R^{2}=0.647 \sim 0.914, p<0.05$, and the growth rates in different groups all increase monotonously with time before they reached their peak values, respectively, and then all decrease monotonously. In addition, $\mu_{c \max }^{\prime}$ for M0, M50, M100 and M200 are $85.486,50.786,36.035$ and $17.24610^{4}$ cells $\cdot(\mathrm{mL} \cdot \mathrm{d})^{-1}$ respectively (Table 1$)$, showing a decrease with increasing prometryn concentrations, and this conforms to the inhibition effect of prometryn on algae growth. The significant difference analysis shows that only $200 \mu \mathrm{g} \cdot \mathrm{L}^{-1}$ prometryn does have significant effects on the growth rate $(p<0.05)$.
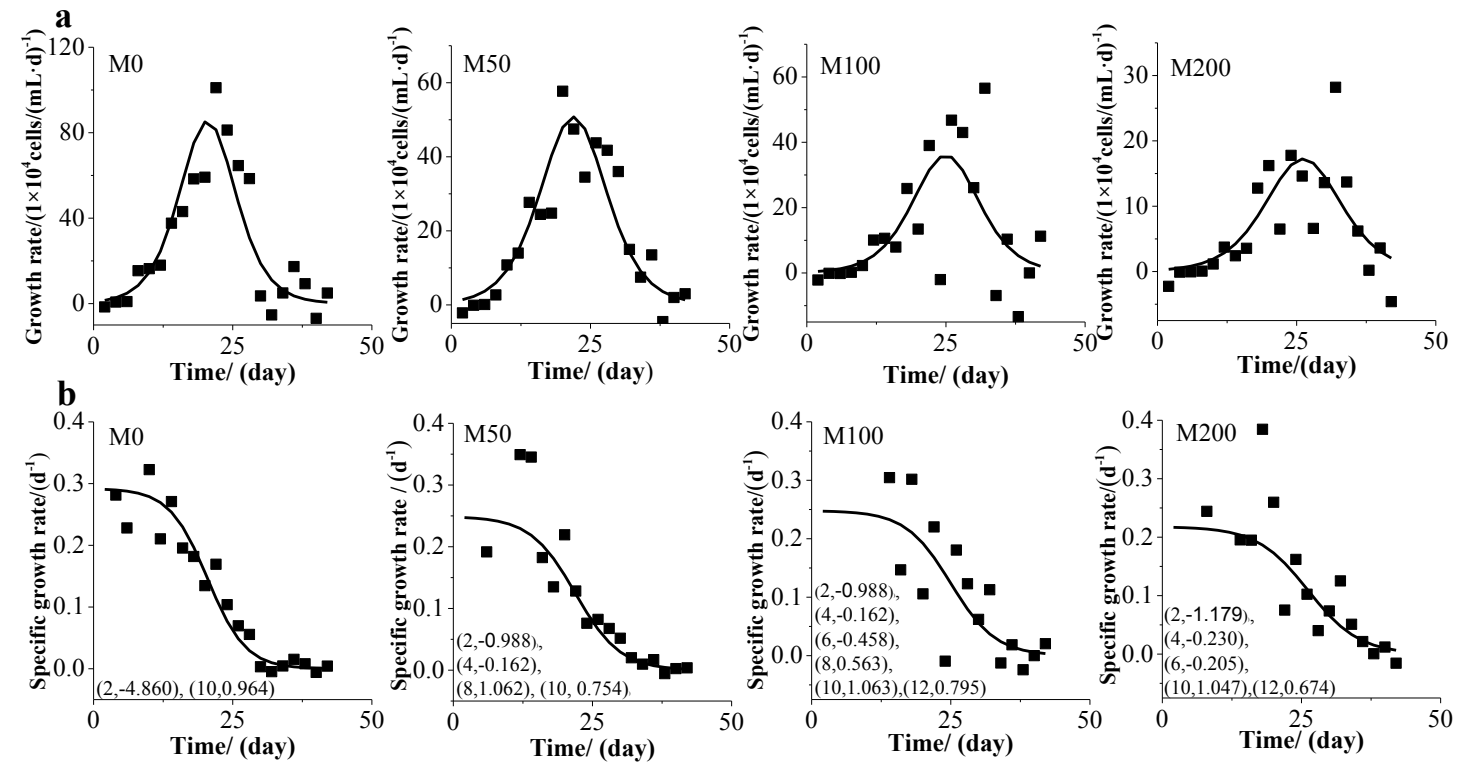

Fig.2 Variations of computed and measured a) growth rates and b) specific growth rates of $M$. aeruginosa with time $\left(\mathrm{M} 0,0 \mu \mathrm{g} \cdot \mathrm{L}^{-1}\right.$ prometryn. $\mathrm{M} 50,50 \mu \mathrm{g} \cdot \mathrm{L}^{-1}$ prometryn. M100, $100 \mu \mathrm{g} \cdot \mathrm{L}^{-1}$ prometryn. M200, $200 \mu \mathrm{g} \cdot \mathrm{L}^{-1}$ prometryn. dots: measured values; lines: computed values) Data shown are average value of two independent measurements.

\subsubsection{Application of Logistic function to compute specific growth rates of $M$.}

\section{aeruginosa}


Correlation analysis between measured and computed specific growth rates including and excluding lag phase were both conducted. Correlation coefficients $\left(R^{2}\right)$ excluding lag phase range from 0.723 to $0.967(p<0.01)$, while including lag phase are from 0.085 to 0.417 ( $p=0.060 \sim 0.713)$. This clearly shows that for the specific growth rate, large relative errors of counting algae densities in the lag phase greatly reduced the correlation coefficients. In addition, Fig.2b did not show those measured specific growth rates if they deviated too much from their computed counterparts, and instead they appeared on the figure as data pairs.

As shown in Fig.2b, the specific growth rates in different groups decrease slowly for about first 15 days, then followed by a fast decrease to almost $0 \mathrm{~d}^{-1}$. This implies that the specific growth rate experiences an autonomous decrease in the whole experimental period. The maximal specific growth rates $\left(\mu_{\text {cmax }}=\frac{r e^{a}}{1+e^{a}}\right)$ for M0, M50, M100 and M200 groups, appearing at the very beginning, are $0.291 \mathrm{~d}^{-1}, 0.247 \mathrm{~d}^{-1}$, $0.247 \mathrm{~d}^{-1}$ and $0.217 \mathrm{~d}^{-1}$, respectively. The maximal specific growth rates in different groups decrease with increasing prometryn concentrations, which also show inhibition effects of prometryn on algae. However, the significant difference analysis does not show that the prometryn concentration influences the specific growth rate significantly $(p>0.05)$.

\subsubsection{Application of Logistic function to compute inhibition rates of $M$.} aeruginosa

Inhibition of prometryn on algae growth is concentration-dependent. From Fig.3 and Table 1, inhibition rate (both measured and computed ones) and percentage inhibition $(I)$ increase with increasing prometryn concentrations, which conforms to the inhibition effect of prometryn on algae. $I^{\prime}$ is $6.8 \%, 13.4 \%$ and $25.4 \%$, respectively, 
for prometyn from low to high concentrations (Table 1). What's more, significant difference analysis also shows that there are significant differences in experimental inhibition rates $(p<0.001)$ among M50, M100 and M200.

Inhibition of prometryn on $M$. aeruginosa growth is also time-dependent. Computed inhibition rates, as shown in Fig.3, increases gradually for about first 20 days, and then followed by a slow decrease in the following days. While experimental inhibition rates increased rapidly and then followed by a decrease during the first about 12 days (in Fig.3), which is not the same as that of computed inhibition rates exactly in lag phase. Thus, a correlation analysis of inhibition rates between measured and computed was conducted, and the results of including and excluding lag phase are depicted in Fig.3. $R^{2}$ excluding lag phase ranges from 0.535 to 0.951 (M50, $n=15$; M100 and M200, $n=13, p<0.05$ ), while including lag phase it ranges from 0.237 to 0.657 ( $n=22, p=0.001 \sim 0.288$ ). Also, we believe that the large relative errors of counting algae densities in lag phase reduce the correlation coefficients greatly.

Jin et al. (2012) focused on analysis of bioaccumulation and degradation of prometryn on Chlamydomonas reinhardtii, and their results show that the algae with prometryn at $2.5 \sim 12.5 \mu \mathrm{g} \cdot \mathrm{L}^{-1}$ for 4 days or $7.5 \mu \mathrm{g} \cdot \mathrm{L}^{-1}$ for $1 \sim 6$ days accumulated a large quantity of prometryn. In our study, we did not detect variations of prometryn concentrations with time due to technical limitations. However, correlation analysis between inhibition rates and algae densities show that the correlation coefficients $\left(R^{2}\right)$ in lag phase only (M50, 0 12 days; M100 and M200, $0 \sim 16$ days; $R^{2}=-0.214 \sim 0.061$ ), after lag phase (M50, 13 42 days; M100 and M200, 17 42 days; $R^{2}=-0.961 \sim-0.701$ ) and in the whole experimental period $\left(0 \sim 42\right.$ days; $\left.R^{2}=-0.537 \sim-0.131\right)$ are almost negative (except of $R^{2}$ of M100 and M200 in lag phase only), although absolute values of $R^{2}$ in lag phase and the whole experimental period are quite small compared 
to those after lag phase (-0.701 -0.961), which may be also caused by relative large errors of counting algae densities in lag phase. In exponential phase and stationary phase (after lag phase), the inhibitory effect of prometryn on M. aeruginosa decreased with increasing algae density obviously. Consistently with our results, other researchers have also observed such inhibition effect of triazine herbicides on algae. This could be attributed to biodegradation of herbicides, biological adaptation and reduction of herbicide in algal cells (Tang et al., 1997; Liebig et al., 2008).

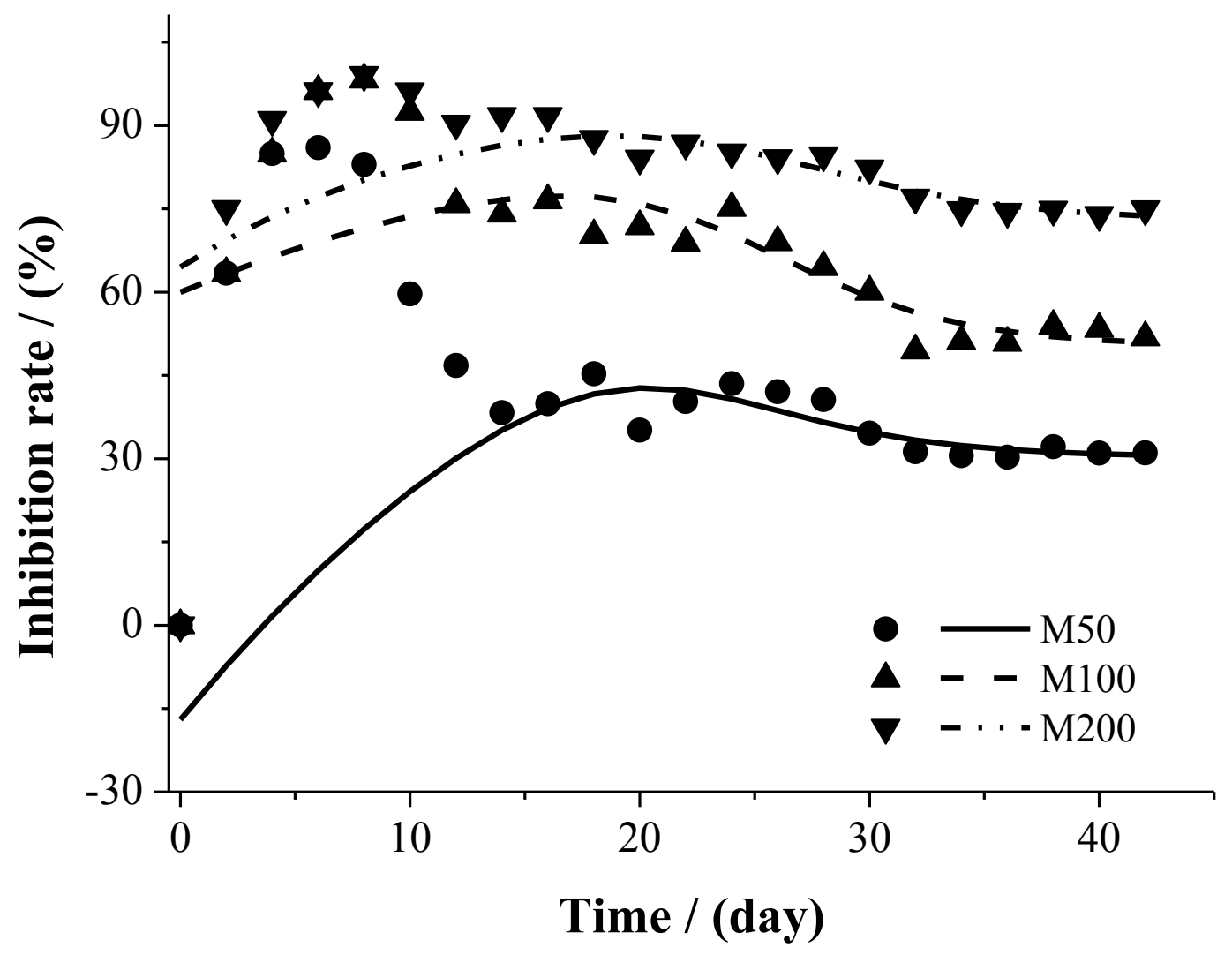

Fig.3 Variations of inhibition ratio of prometryn under different fish food dosages (M50, $50 \mu \mathrm{g} \cdot \mathrm{L}^{-1}$ prometryn. M100, $100 \mu \mathrm{g} \cdot \mathrm{L}^{-1}$ prometryn. M200, $200 \mu \mathrm{g} \cdot \mathrm{L}^{-1}$ prometryn. dots: measured values; lines: computed values) Data shown are average value of two independent measurements.

\subsubsection{Kinetics of $\mathrm{PO}_{4}{ }^{3-}-\mathrm{P}$ and $\mathrm{NH}_{4}{ }^{+}-\mathrm{N}$ consumption based on Logistic function}

In the present study, from Fig. 4 and Table 2, Eq. (5) can well describe variations 
of $\triangle \mathrm{PO}_{4}{ }^{3-}-\mathrm{P}$ and $\triangle \mathrm{NH}_{4}{ }^{+}-\mathrm{N}$ concentrations with time $\left(R^{2}=0.694 \sim 0.994\right)$. In Fig. 4, consumed $\mathrm{PO}_{4}{ }^{3-}-\mathrm{P}$ and $\mathrm{NH}_{4}{ }^{+}-\mathrm{N}$ concentrations increase rapidly until it reaches the maximal consumed concentration, and then it remains stable. And this tendency conforms to variations of $\mathrm{PO}_{4}{ }^{3-}-\mathrm{P}$ and $\mathrm{NH}_{4}{ }^{+}-\mathrm{N}$ concentrations in Fig. $1 \mathrm{~b}$ and c. As shown in Fig. 4, algae can consume large amount of nutrients in lag phase even though the algae densities are low, and the time to reach the maximum consumed nutrient concentration increases with increasing prometryn concentrations. In Table 2, $\Delta C_{\max }$ of $\mathrm{PO}_{4}{ }^{3-}-\mathrm{P}$ is $0.330 \sim 0.344 \mathrm{mg} / \mathrm{L}$, and $\Delta C_{\max }$ of $\mathrm{NH}_{4}{ }^{+}-\mathrm{N}$ is $0.207 \sim 0.213 \mathrm{mg} / \mathrm{L}$. For the same nutrient, $\Delta C_{\max }$ in every group is quite close because the nutrient can be depleted by algae in all groups. In addition, $r_{\Delta C}$ decreases with increasing prometryn concentrations $\left(0 \sim 200 \mu \mathrm{g} \cdot \mathrm{L}^{-1}\right)$ generally, and this may be because $50 \sim 200 \mu \mathrm{g} \cdot \mathrm{L}^{-1}$ promentryn has an inhibition effect on uptaking nutrients of $M$. aeruginosa.

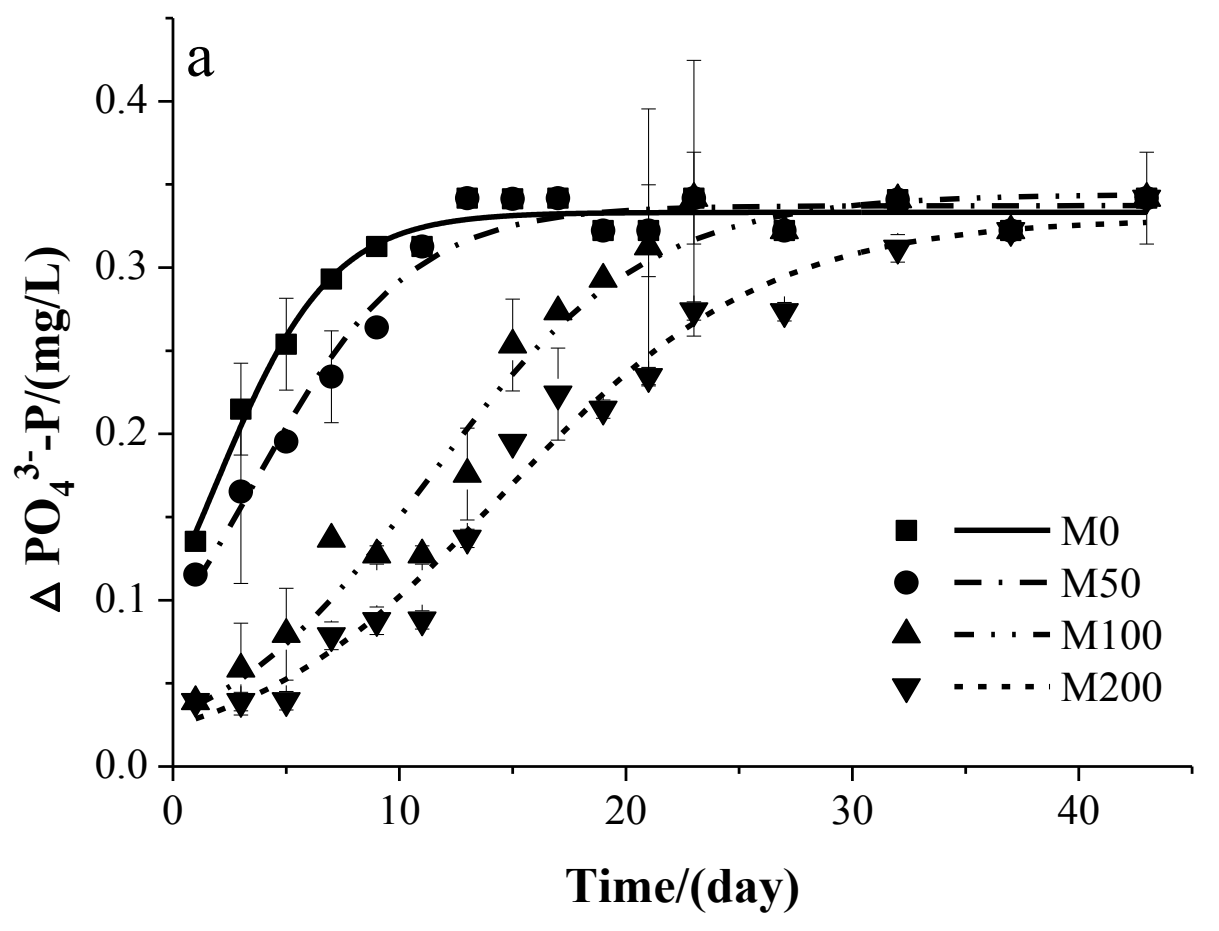




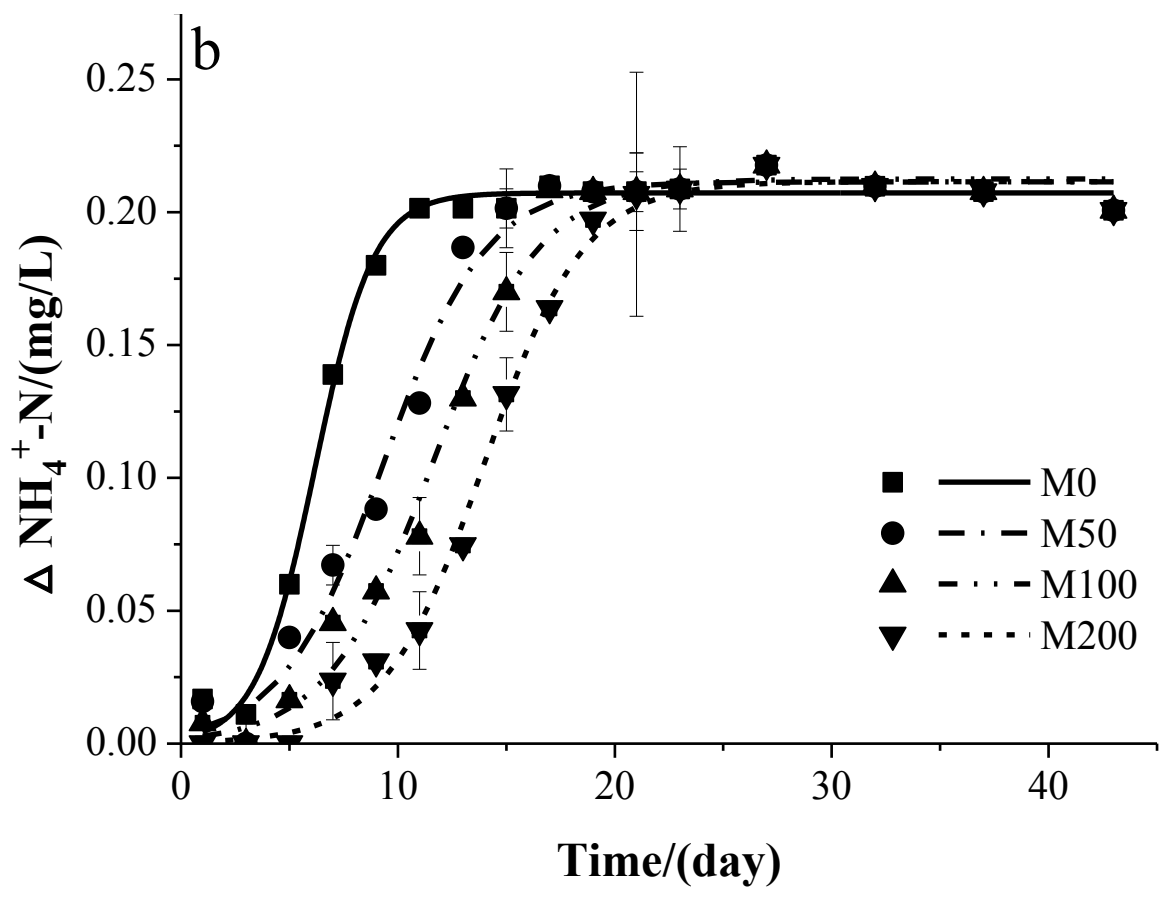

Fig.4 Variations of consumed $\mathrm{PO}_{4}{ }^{3-}-\mathrm{P}$ and $\mathrm{NH}_{4}{ }^{+}-\mathrm{N}$ concentrations with time (M0, 0 $\mu \mathrm{g} \cdot \mathrm{L}^{-1}$ prometryn; M50, $50 \mu \mathrm{g} \cdot \mathrm{L}^{-1}$ prometryn; M100, $100 \mu \mathrm{g} \cdot \mathrm{L}^{-1}$ prometryn; M200, $200 \mu \mathrm{g} \cdot \mathrm{L}^{-1}$ prometryn. dots: measured values; lines: computed values) Data shown is the mean $\pm \mathrm{SD}$ of two independent measurements.

Table 2 Parameters of Logistic function describing consumed $\mathrm{PO}_{4}{ }^{3-}-\mathrm{P}$ and $\mathrm{NH}_{4}{ }^{+}-\mathrm{N}$ concentrations

\begin{tabular}{ccccc}
\hline \multicolumn{5}{c}{$\mathrm{PO}_{4}{ }^{3-}-\mathrm{P}$} \\
\hline Parameter & $\mathrm{M} 0$ & $\mathrm{M} 50$ & $\mathrm{M} 100$ & $\mathrm{M} 200$ \\
\hline$a_{\Delta C}$ & 0.702 & 1.013 & 2.337 & 2.524 \\
$r_{\Delta C}\left(\mathrm{~d}^{-1}\right)$ & 0.389 & 0.287 & 0.208 & 0.172 \\
$\Delta C_{\max }(\mathrm{mg} / \mathrm{L})$ & 0.333 & 0.337 & 0.344 & 0.330 \\
$R^{2}$ & 0.969 & 0.964 & 0.967 & 0.978 \\
\hline \multicolumn{5}{c}{$\mathrm{NH}_{4}^{+}-\mathrm{N}$} \\
\hline Parameter & $\mathrm{M} 0$ & $\mathrm{M} 50$ & $\mathrm{M} 100$ & $\mathrm{M} 200$ \\
\hline$a_{\Delta C}$ & 4.583 & 3.954 & 4.724 & 6.093 \\
$r_{\Delta C}\left(\mathrm{~d}^{-1}\right)$ & 0.742 & 0.423 & 0.406 & 0.435 \\
$\Delta C_{\max }(m g / L)$ & 0.207 & 0.211 & 0.213 & 0.212 \\
$R^{2}$ & 0.993 & 0.985 & 0.988 & 0.994 \\
\hline
\end{tabular}

$a_{\Delta C}:$ a constant; $r_{\Delta C}:$ the consumed rate constant; $\Delta C_{\max }$ : the maximum consumed nutrient concentrations; $R^{2}$ : correlation coefficient. Data are obtained by fitting to two independent measurements.

\subsubsection{Relationships between algae density and nutrients utilization}


Measured algae densities and computed algae densities as a function of computed consumed $\mathrm{PO}_{4}{ }^{3-}-\mathrm{P}$ or $\mathrm{NH}_{4}{ }^{+}-\mathrm{N}$ concentrations are displayed in Fig.5, respectively and their correlation analyses are also conducted. It shows that the computed algae densities by Eq. (6) agree well to measured ones with $R^{2}=0.860 \sim 0.986, p<0.001$ (as a function of consumed $\mathrm{PO}_{4}{ }^{3-}-\mathrm{P}$ concentrations) and $R^{2}=0.776 \sim 0.942, p<0.001 \quad$ (as a function of consumed $\mathrm{NH}_{4}{ }^{+}-\mathrm{N}$ concentrations), respectively.

From Fig. 5, both computed algae densities by Eq. (6) and measured algae densities increase slowly with increasing consumed $\mathrm{PO}_{4}{ }^{3-}-\mathrm{P}$ or $\mathrm{NH}_{4}{ }^{+}-\mathrm{N}$ concentrations in lag phase because a large amount of nutrients is consumed from the environment even though the algae density is low during this phase. And then algal densities increase rapidly when consumed $\mathrm{PO}_{4}{ }^{3-}-\mathrm{P}$ or $\mathrm{NH}_{4}{ }^{+}-\mathrm{N}$ concentrations close to maximal values in exponential and stationary phase. This phenomenon conforms to the studies of Droop (1973, 1983) and Cerucci et al. (2010), and they believe that algae can take up and store nutrients at higher rates than that necessary for growth at times of excess nutrient availability in water, and the stored nutrients can be used to support algae growth at times of low nutrient availability in water. And this phenomenon is called nutrient luxury uptake (Droop 1973; Droop 1983; Cerucci et al., 2010).

Fig. 5 also show the fitted results using Eq. (7) for describing the relationship between algae densities and consumed $\mathrm{PO}_{4}{ }^{3-}-\mathrm{P}$ and $\mathrm{NH}_{4}{ }^{+}-\mathrm{N}$ concentrations, respectively, and it also describes the relationship reasonably well with $R^{2}=0.271 \sim 0.973 \quad$ (as a function of consumed $\mathrm{PO}_{4}{ }^{3-}-\mathrm{P}$ concentrations) and $R^{2}=0.488 \sim 0.565$ (as a function of consumed $\mathrm{NH}_{4}{ }^{+}-\mathrm{N}$ concentrations). However, it is obvious that the correlation coefficients between measured and computed algae densities by Eq. (7) are lower than those of Eq.(6). Thus, Eq.(6) is more reasonable 
than Eq.(7) to predict algae densities using consumed $\mathrm{PO}_{4}^{3-}-\mathrm{P}$ or $\mathrm{NH}_{4}^{+}-\mathrm{N}$ concentrations.

Wu et al.'s (2012) study concluded that the relationship between algae densities and $\mathrm{NH}_{4}{ }^{+}-\mathrm{N}$ utilization is linear, but such linear equation is not suitable for our study. This may be because in $\mathrm{Wu}$ et al.'s (2012) study the experimental period is only 20 days while our experimental period is 43 days.
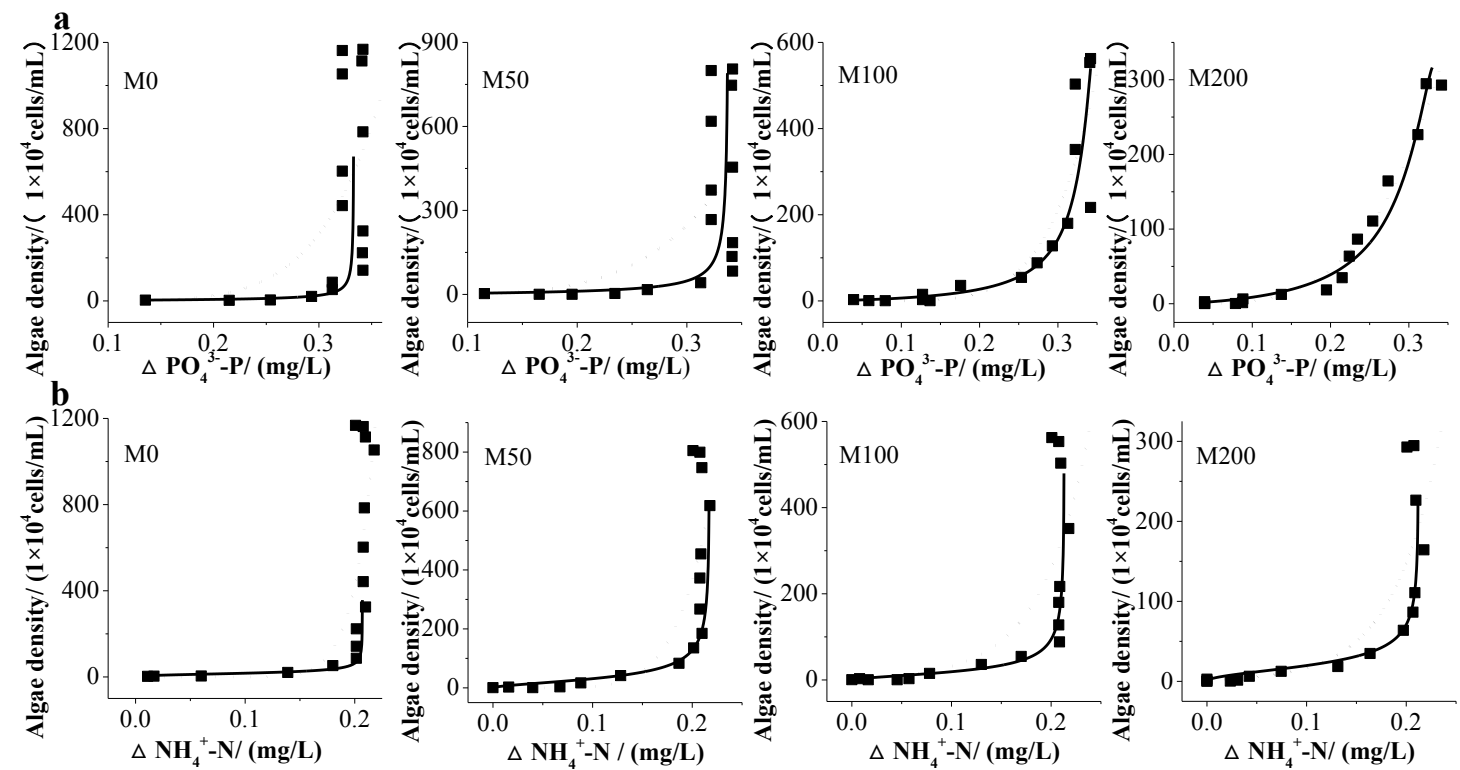

Fig.5 Relationships between algae densities and consumed nutrients concentrations: a) consumed $\mathrm{PO}_{4}{ }^{3-}-\mathrm{P}$ concentrations, b) consumed $\mathrm{NH}_{4}{ }^{+}-\mathrm{N}$ concentrations $\left(\mathrm{M} 0,0 \mu \mathrm{g} \cdot \mathrm{L}^{-1}\right.$ prometryn; M50, $50 \mu \mathrm{g} \cdot \mathrm{L}^{-1}$ prometryn; M100, $100 \mu \mathrm{g} \cdot \mathrm{L}^{-1}$ prometryn; M200, 200 $\mu \mathrm{g} \cdot \mathrm{L}^{-1}$ prometryn. dots: measured values; solid lines: computed values by Eq.(6); dashed lines: computed values by Eq.(7)) Data shown are the average value of two independent measurements.

\subsection{Application of Monod function alone}

In Monod function, Eq. (8), time is an implicit variable, which makes it difficult to parse $\mu_{m}$ and $K_{c}$ in most experiments directly. Several methods are used to describe algae growth with Monod function (Li et al., 2010; Qiao and Yu, 2014; Kayombo et al., 2003; Zhu et al., 2017). Zhu et al. (2017) use Monod function to describe 
relationship between average algal specific growth rates and corresponding initial nutrients concentrations. In Li et al.'s (2010) and Qiao et al.'s (2014) studies, the maximal population growth rates are calculated under different initial nutrients concentrations, and relationships between maximal population growth rates and initial nutrients concentrations are also described well by Monod function (Kayombo et al., 2003). Zeng et al. (2016) and Sunda et al. (2009) consider that the specific growth rate is a function of time, and they estimate it as the slope of the log-transformed concentration of chlorophyll a versus time.

As shown in Table 3, the dataset of measured specific growth rates and corresponding $\mathrm{PO}_{4}{ }^{3-}-\mathrm{P}$ concentrations in Groups of M0 and M50 does not conform to Monod function owing to errors of counting algae cells especially in lag phase. In other groups, Monod function could fit the dataset of measured specific growth rates and nutrient concentrations, and their correlations coefficients $\left(R^{2}\right)$ are quite low (0.009 0.170) and errors are quite large (Table 3). To overcome these difficulties, we propose a method of combined Monod with Logistic functions, that is, instead of using the dataset of measured specific growth rates and nutrients concentrations, we use the dataset of computed specific growth rates by fitted Logistic function and measured nutrients concentrations to fit Monod function and thus determine the parameters $\mu_{m}$ and $K_{c}$ in Monod function.

Table 3 Parameters of Monod function and errors in fitting

\begin{tabular}{ccccccc}
\hline \multicolumn{7}{c}{ Parameters when using Monod function alone (Eq. 8) } \\
\hline Group & $\begin{array}{c}\text { Correlation } \\
\text { coefficient }\end{array}$ & $\mu_{m} / \mathrm{d}^{-1}$ & $K_{c} / \mathrm{mg}^{3} \cdot \mathrm{L}^{-1}-\mathrm{P}$ & $E / \mathrm{d}^{-1}$ & $R E /-$ & $R M S E / \mathrm{d}^{-1}$ \\
\hline M0 & Fit failed & - & - & - & - & - \\
M50 & Fit failed & - & - & - & - & - \\
M100 & $R^{2}=0.028$ & 0.333 & $8.29 \times 10^{-3}$ & $-0.78 \sim 0.74$ & $0.016 \sim 2.98$ & 0.342 \\
M200 & $R^{2}=0.020$ & 0.349 & $6.18 \times 10^{-2}$ & $-0.51 \sim 0.77$ & $0.11 \sim 2.38$ & 0.447 \\
\hline
\end{tabular}




\begin{tabular}{ccccccc}
\hline \multicolumn{7}{c}{$\mathrm{NH}_{4}{ }^{+}-\mathrm{N}$} \\
\hline Group & $\begin{array}{c}\text { Correlation } \\
\text { coefficient }\end{array}$ & $\mu_{m} / \mathrm{d}^{-1}$ & $K_{c} / \mathrm{mg}^{-1} \mathrm{~L}^{-1}$ & $E / \mathrm{d}^{-1}$ & $R E /-$ & $R M S E / \mathrm{d}^{-1}$ \\
\hline M0 & $R^{2}=0.140$ & 0.462 & $1.55 \times 10^{-3}$ & $-0.22 \sim 0.51$ & $0.40 \sim 1.05$ & 0.201 \\
M50 & $R^{2}=0.170$ & 0.440 & $2.33 \times 10^{-3}$ & $-0.60 \sim 0.63$ & $0.22 \sim 3.68$ & 0.265 \\
M100 & $R^{2}=0.009$ & 0.322 & $1.16 \times 10^{-4}$ & $-0.78 \sim 0.74$ & $0.012 \sim 2.98$ & 0.346 \\
M200 & $R^{2}=0.030$ & 0.293 & $1.93 \times 10^{-3}$ & $-0.52 \sim 0.76$ & $0.045 \sim 2.42$ & 0.296 \\
\hline
\end{tabular}

\begin{tabular}{|c|c|c|c|c|c|c|}
\hline \multicolumn{7}{|c|}{ Parameters when jointly applying Logistic and Monod functions (Eq. 9) } \\
\hline \multicolumn{7}{|c|}{$\mathrm{PO}_{4}{ }^{3-}-\mathrm{P}$} \\
\hline Group & $\begin{array}{l}\text { Correlation } \\
\text { coefficient }\end{array}$ & $\mu_{m} / \mathrm{d}^{-1}$ & $K_{c} / \mathrm{mg} \cdot \mathrm{L}^{-1}$ & $E / \mathrm{d}^{-1}$ & $R E /-$ & $R M S E / \mathrm{d}^{-1}$ \\
\hline M0 & $\mathrm{R}^{2}=0.990$ & 0.292 & $4.74 \times 10^{-4}$ & $-0.0028 \sim 0.28$ & $0.0017 \sim 1$ & 0.148 \\
\hline M50 & $\mathrm{R}^{2}=0.966$ & 0.250 & $1.99 \times 10^{-3}$ & $-0.0033 \sim 0.23$ & $0.00041 \sim 1$ & 0.144 \\
\hline M100 & $\mathrm{R}^{2}=0.860$ & 0.245 & $5.54 \times 10^{-3}$ & $-0.016 \sim 0.14$ & $0.0024 \sim 1$ & 0.091 \\
\hline M200 & $\mathrm{R}^{2}=0.907$ & 0.225 & $3.87 \times 10^{-2}$ & $-0.049 \sim 0.023$ & $0.0044 \sim 1.02$ & 0.113 \\
\hline \multicolumn{7}{|c|}{$\mathrm{NH}_{4}^{+}-\mathrm{N}$} \\
\hline Group & $\begin{array}{l}\text { Correlation } \\
\text { coefficient }\end{array}$ & $\mu_{m} / \mathrm{d}^{-1}$ & $K_{c} / \mathrm{mg} \cdot \mathrm{L}^{-1}$ & $E / \mathrm{d}^{-1}$ & $R E /-$ & $R M S E / \mathrm{d}^{-1}$ \\
\hline M0 & $\mathrm{R}^{2}=0.957$ & 0.293 & $1.8 \times 10^{-3}$ & $-0.0048 \sim 0.25$ & $0.0028 \sim 1$ & 0.112 \\
\hline M50 & $\mathrm{R}^{2}=0.963$ & 0.254 & $5.84 \times 10^{-3}$ & $-0.0056 \sim 0.20$ & $0.0011 \sim 1$ & 0.088 \\
\hline M100 & $\mathrm{R}^{2}=0.972$ & 0.253 & $5.23 \times 10^{-3}$ & $-0.0042 \sim 0.19$ & $0.00087 \sim 1$ & 0.085 \\
\hline M200 & $\mathrm{R}^{2}=0.968$ & 0.227 & $1.06 \times 10^{-2}$ & $-0.0058 \sim 0.14$ & $0.00027 \sim 1$ & 0.056 \\
\hline
\end{tabular}

\subsection{Application of Combined Logistic with Monod functions}

\subsubsection{Relationship between specific growth rates and nutrients concentrations}

Fig. 6 and Table 3 show the results of jointly applying Logistic and Monod functions, and they indicate that the method of joint application of Monod and Logistic functions are much better in determining the specific growth rate as a function of measured $\mathrm{PO}_{4}{ }^{3-}-\mathrm{P}$ or $\mathrm{NH}_{4}{ }^{+}-\mathrm{N}$ concentrations with $R^{2}=0.860 \sim 0.990$ than the application of Monod fucntion alone. The specific growth rate for each group increases rapidly at lower nutrients concentrations, as shown in Fig. 6, and then slowly increases and keeps stable with increasing nutrients concentrations. Moreover, 
errors $\left(-0.049 \sim 0.28 \mathrm{~d}^{-1}\right)$, relative errors $(0.00027 \sim 1)$ and $R M S E\left(0.056 \sim 0.148 \mathrm{~d}^{-1}\right)$ by this method are clearly much smaller than those in the application of Monod function alone, justfying the joint application of Monod and Logistic functions (Eq. 9). In Table 3, the maximal specific growth rates $\left(\mu_{m}\right)$ decreases with the increase of prometryn concentrations. The half saturation constant $\left(K_{c}\right)$ in Monod function is often referred to as the affinity constant of substrate (Zhu et al., 2017). As seen in Table 3, the higher the prometyn concentration is, the higher the $K_{c}$ of $\mathrm{PO}_{4}{ }^{3-}-\mathrm{P}$ and $\mathrm{NH}_{4}{ }^{+}-\mathrm{N}$ for algae growth in medium basically, which suggests a lower affinity of algae for medium with higher prometryn concentrations.

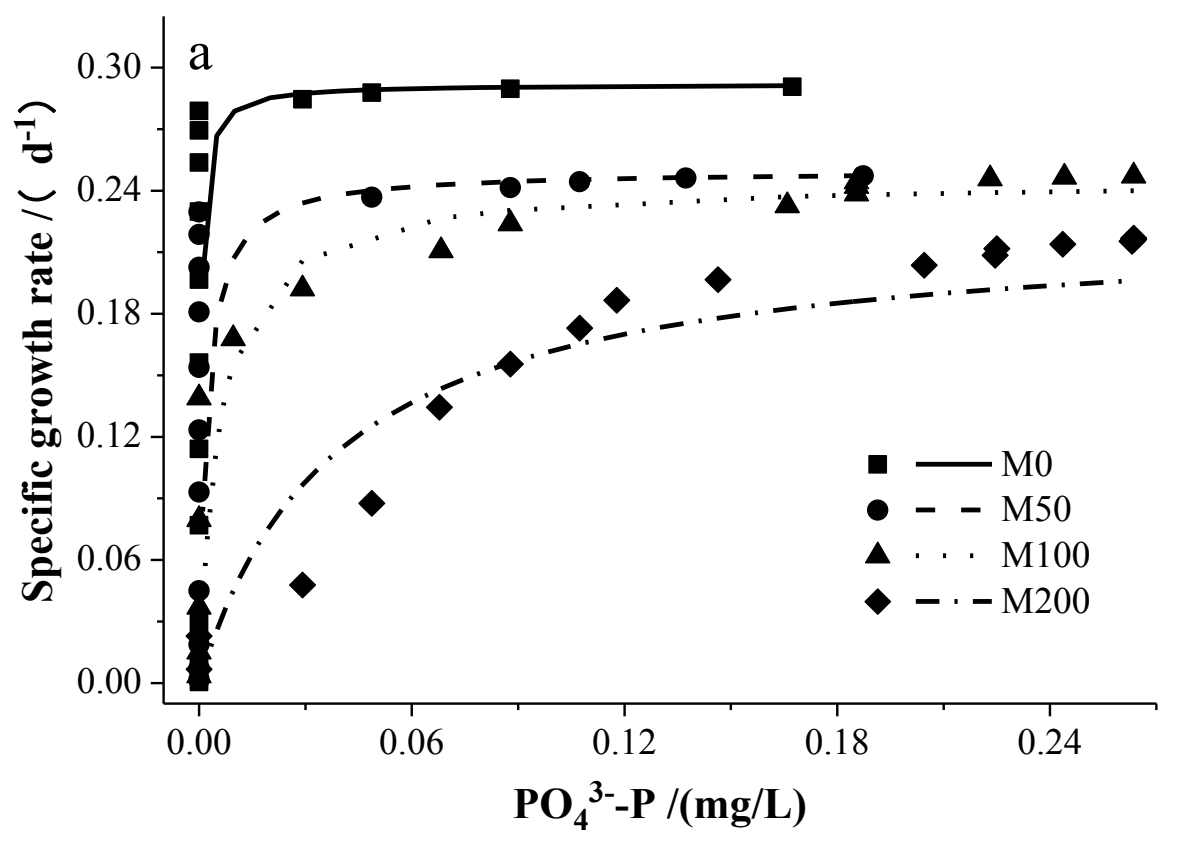




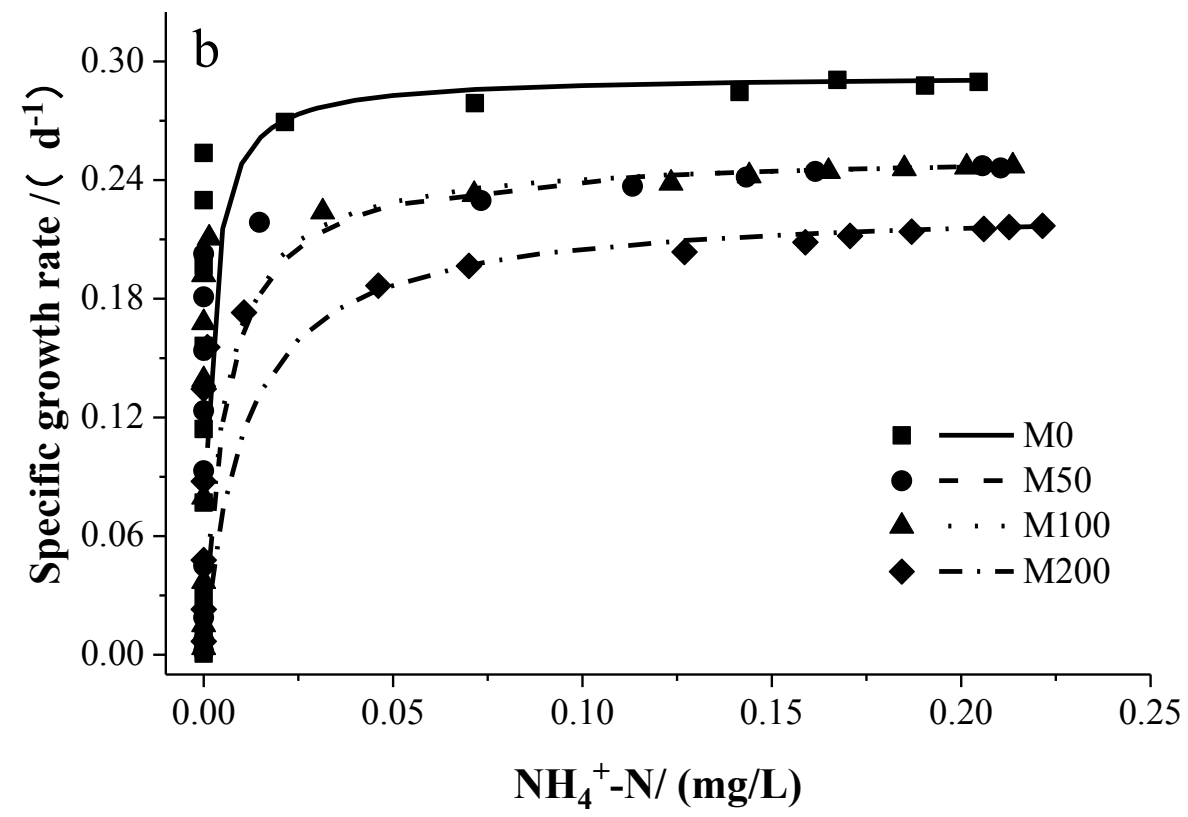

Fig.6 Fitting curves of Monod function to the datasets of computed specific growth rates by Logistic function and measured nutrients concentrations: a) $\mathrm{PO}_{4}{ }^{3-}-\mathrm{P}$ concentrations, b) $\mathrm{NH}_{4}{ }^{+}-\mathrm{N}$ concentrations (M0, $0 \mu \mathrm{g} \cdot \mathrm{L}^{-1}$ prometryn; M50, $50 \mu \mathrm{g} \cdot \mathrm{L}^{-1}$ prometryn; M100, $100 \mu \mathrm{g} \cdot \mathrm{L}^{-1}$ prometryn; $\mathrm{M} 200,200 \mu \mathrm{g} \cdot \mathrm{L}^{-1}$ prometryn. dots: measured values; lines: computed values Eq.(9)) Data shown are computed values based on Fig.2.

\subsubsection{Variations of $\mathrm{PO}_{4}{ }^{3-}-\mathrm{P}$ and $\mathrm{NH}_{4}{ }^{+}-\mathrm{N}$ concentrations with time}

Variations of computed $\mathrm{PO}_{4}{ }^{3-}-\mathrm{P}$ and $\mathrm{NH}_{4}{ }^{+}-\mathrm{N}$ concentrations with time by the use of Eq. (10) for groups with algae (M0, M50, M100 and M2000) are shown in Fig.1b and $\mathrm{c}$, indicating that computed $\mathrm{PO}_{4}{ }^{3-}-\mathrm{P}$ and $\mathrm{NH}_{4}{ }^{+}-\mathrm{N}$ concentrations decreases to zero as time goes, which are in good agreement to the measured ones. Correlation analysis also shows that there are significant correlations with $R^{2}=0.981 \sim 0.996 \quad(p<0.05)$ between measured and computed nutrients concentrations, as shown in Fig.1b and c, manifesting that Eq. (10) can be used to predict variations of $\mathrm{PO}_{4}{ }^{3-}-\mathrm{P}$ and $\mathrm{NH}_{4}{ }^{+}-\mathrm{N}$ concentrations with time in groups with algae in the present experiment.

\subsection{Other discussions on algal growth}




\subsubsection{Discussion on demarcation points of algal growth phases}

Comparing Fig. 1a and Fig. 7, we define $t_{1}$ (Eq. 11a) and $t_{3}$ (Eq. 11b) respectively as critical times to distinguish between the lag phase and exponential phase, and between the exponential phase and stationary phase based on properties of derivatives of functions. It can be further deduced that percentages of algae density at $t_{1}$ to the maximal algae density is $\frac{N}{N_{\max }}=\frac{N_{\max }}{6+2 \sqrt{6}} / N_{\max } \approx 0.0918$, while at $t_{3}$ it is $\frac{N}{N_{\max }}=\frac{N_{\max }}{6-2 \sqrt{6}} / N_{\max } \approx 0.9082$ as shown in Table 4 . When $t_{1}$ and $t_{3}$ are taken as demarcation times respectively for the beginning of exponential phase and ending of exponential phase, the measured percentages of algal densities (relative to the maximum measured algal desnities) at $t_{1}(6.96 \% \sim 10.96 \%)$ and $t_{3}(93.04 \% \sim 97.54 \%)$ for M0, M50, M100 and M200 groups are quite close to computed ones $(9.18 \%$, $90.82 \%)$, respectively. This justifies the selection of $t_{1}$ and $t_{3}$ as critical times for predicting the ending of lag phase and the ending of exponential phase. 


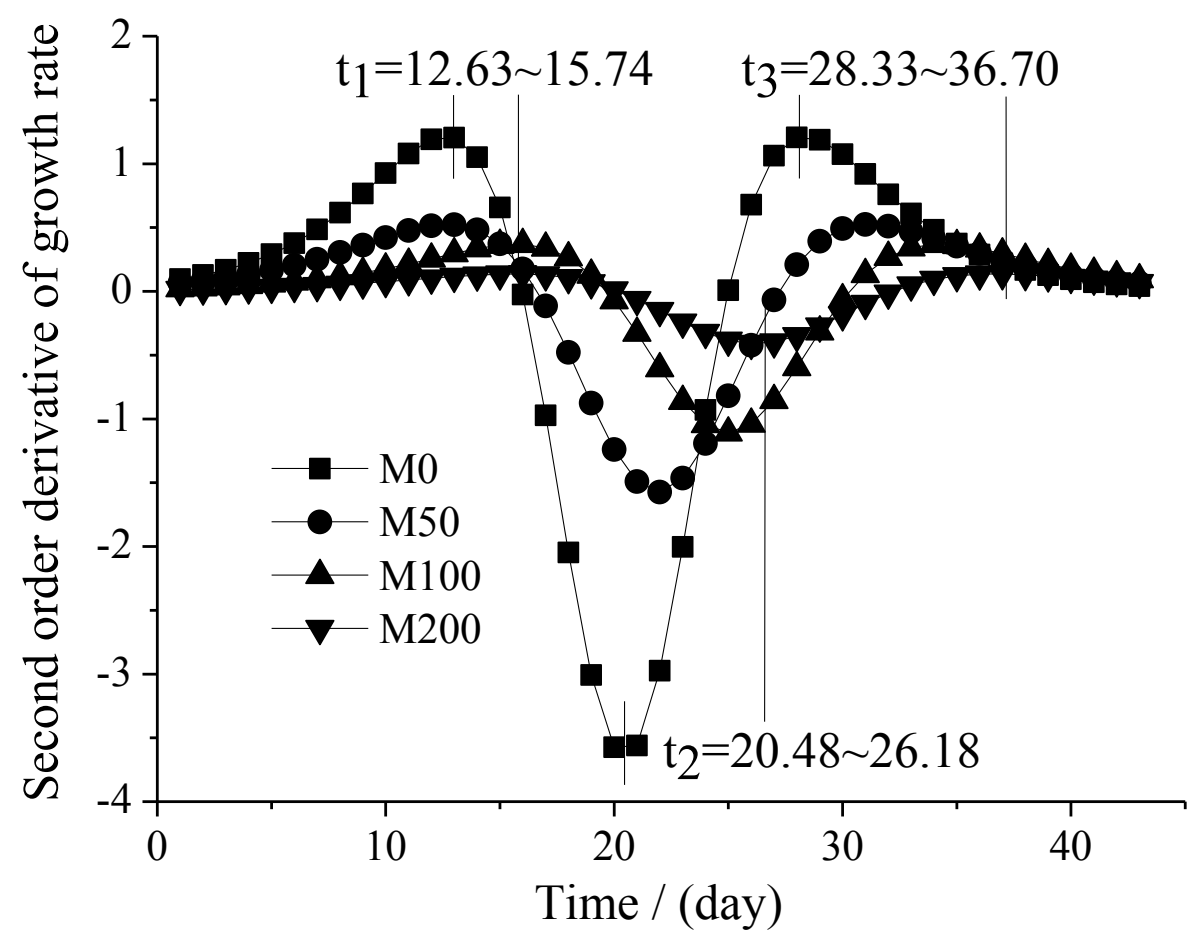

Fig.7 Variations of second order derivatives of growth rates with time $\left(\mathrm{M} 0,0 \mu \mathrm{g} \cdot \mathrm{L}^{-1}\right.$ prometryn; M50, $50 \mu \mathrm{g} \cdot \mathrm{L}^{-1}$ prometryn; M100, $100 \mu \mathrm{g} \cdot \mathrm{L}^{-1}$ prometryn; M200, 200 $\mu \mathrm{g} \cdot \mathrm{L}^{-1}$ prometryn.) Data shown are computed value.

Table 4 Computed algae density, algae growth rate and algae specific growth rate at critical point of algae growth phase based on Logistic function

\begin{tabular}{|c|c|c|c|c|c|}
\hline Indicator & Period & M0 & M50 & M100 & M200 \\
\hline \multirow[t]{3}{*}{ Critical time } & $\overline{t_{1} \text { (day) }}$ & 12.63 & 12.72 & 15.74 & 15.66 \\
\hline & $t_{2}$ (day) & 20.48 & 21.93 & 24.98 & 26.18 \\
\hline & $t_{3}$ (day) & 28.33 & 31.13 & 34.23 & 36.70 \\
\hline \multirow{3}{*}{$\begin{array}{l}\text { Algae density } \\
\left(10^{4} \text { cells } \cdot \mathrm{ml}^{-1}\right)\end{array}$} & $t_{1}$ & 128.42 & 75.644 & 60.46 & 20.84 \\
\hline & $t_{2}$ & 549.75 & 416.67 & 260.79 & 158.99 \\
\hline & $t_{3}$ & 1113.19 & 748.95 & 548.38 & 294.58 \\
\hline \multirow{2}{*}{$\%$} & $P t_{1}$ & $10.96 \%$ & $9.40 \%$ & $10.75 \%$ & $6.90 \%$ \\
\hline & $\mathrm{Pt}_{3}$ & $95.00 \%$ & $93.04 \%$ & $96.77 \%$ & $97.54 \%$ \\
\hline$P c t_{1}=\frac{1}{\mathbf{6 + 2 \sqrt { 6 }}}(\%)$ & \multicolumn{5}{|c|}{$9.18 \%$} \\
\hline$P c t_{3}=\frac{1}{6-2 \sqrt{6}}(\%)$ & \multicolumn{5}{|c|}{$90.82 \%$} \\
\hline \multicolumn{6}{|c|}{$\begin{array}{l}P t_{1} \text { and } P t_{3} \text { represent percentage of measured algae densities to corresponding } \\
\text { measured maximal values }\left(N_{\max }\right) \text { at } t_{1} \text { and } t_{3} \text {, respectively. And } P c t_{1} \text { and } P c t_{3} \text { represent } \\
\text { derived percentages at } t_{1} \text { and } t_{3} \text { based on functions of algae density to corresponding } \\
\text { computed maximal values, respectively. Data shown are average value of two } \\
\text { indenendent measurements. }\end{array}$} \\
\hline
\end{tabular}

\subsubsection{Discussion on limiting nutrients of algae growth}


In aquatic ecosystems models, $\mathrm{N}$ or $\mathrm{P}$ is often used as a nutrient driver for phytoplankton growth, and describes the interactions and correlations between nutrients and the growth and extinction of phytoplankton. Based on the Liebig's law of the minimum, $\mathrm{N}$ or $\mathrm{P}$ limiting is a key factor to determine the change of algae (Hiddink and Kaiser, 2005; Perini and Bracken, 2014). In various models such as dynamic nutrient driven phytoplankton model (Li et al., 2015; Law et al., 2009; Liu et al., 2010; Liu and Scavia, 2010), WASP model (Pilar et al., 1997; Wang et al., 1999), nutrient limits for phytoplankton are expressed by the term $C /(K c+C)$. In our study, both $\mathrm{NH}_{4}{ }^{+}-\mathrm{N}$ and $\mathrm{PO}_{4}{ }^{3-}-\mathrm{P}$ were limiting nutrients according to the above results, but it is interesting to find which nutrient is firstly limited. $\mathrm{C} /(\mathrm{Kc}+\mathrm{C})$ is chosen to judge limiting nutrient in Fig. 8 in our experiment. In groups of M0 and M50, C/(Kc+C) of $\mathrm{PO}_{4}{ }^{3-}-\mathrm{P}$ decrease to 0 before $C /(K c+C)$ of $\mathrm{NH}_{4}{ }^{+}-\mathrm{N}$ decreases to 0 , and $\mathrm{PO}_{4}{ }^{3-}-\mathrm{P}$ can be considered as major limiting nutrient for algae growth. For group of M100, $C /(K c+C)$ of $\mathrm{NH}_{4}{ }^{+}-\mathrm{N}$ is lower than that of $\mathrm{PO}_{4}{ }^{3-}-\mathrm{P}$, and $\mathrm{NH}_{4}{ }^{+}-\mathrm{N}$ is the major limiting nutrient. However, in M200 group, $\mathrm{C} /(\mathrm{Kc}+\mathrm{C})$ of $\mathrm{PO}_{4}{ }^{3-}-\mathrm{P}$ is lower than that of $\mathrm{NH}_{4}{ }^{+}-\mathrm{N}$ in about first 18 days, and $\mathrm{C} /(\mathrm{Kc}+\mathrm{C})$ of $\mathrm{NH}_{4}{ }^{+}-\mathrm{N}$ is lower than those of $\mathrm{PO}_{4}{ }^{3-}-\mathrm{P}$ in the following days, which indicates that the limiting nutrient is shifted from $\mathrm{PO}_{4}{ }^{3-}-\mathrm{P}$ to $\mathrm{NH}_{4}{ }^{+}-\mathrm{N}$ during the experimental period. From the above results, limited nutrients for algae growth are different in different groups with different prometryn concentrations, and shifts of limiting nutrients could be prompted by prometryn concentrations, instead of nutrients availabilities only. The result about limiting nutrients makes us consider that limiting nutrients for algae growth maybe shift in natural fresh water body for phytoplankton, but this remains to be verified in the future research. 

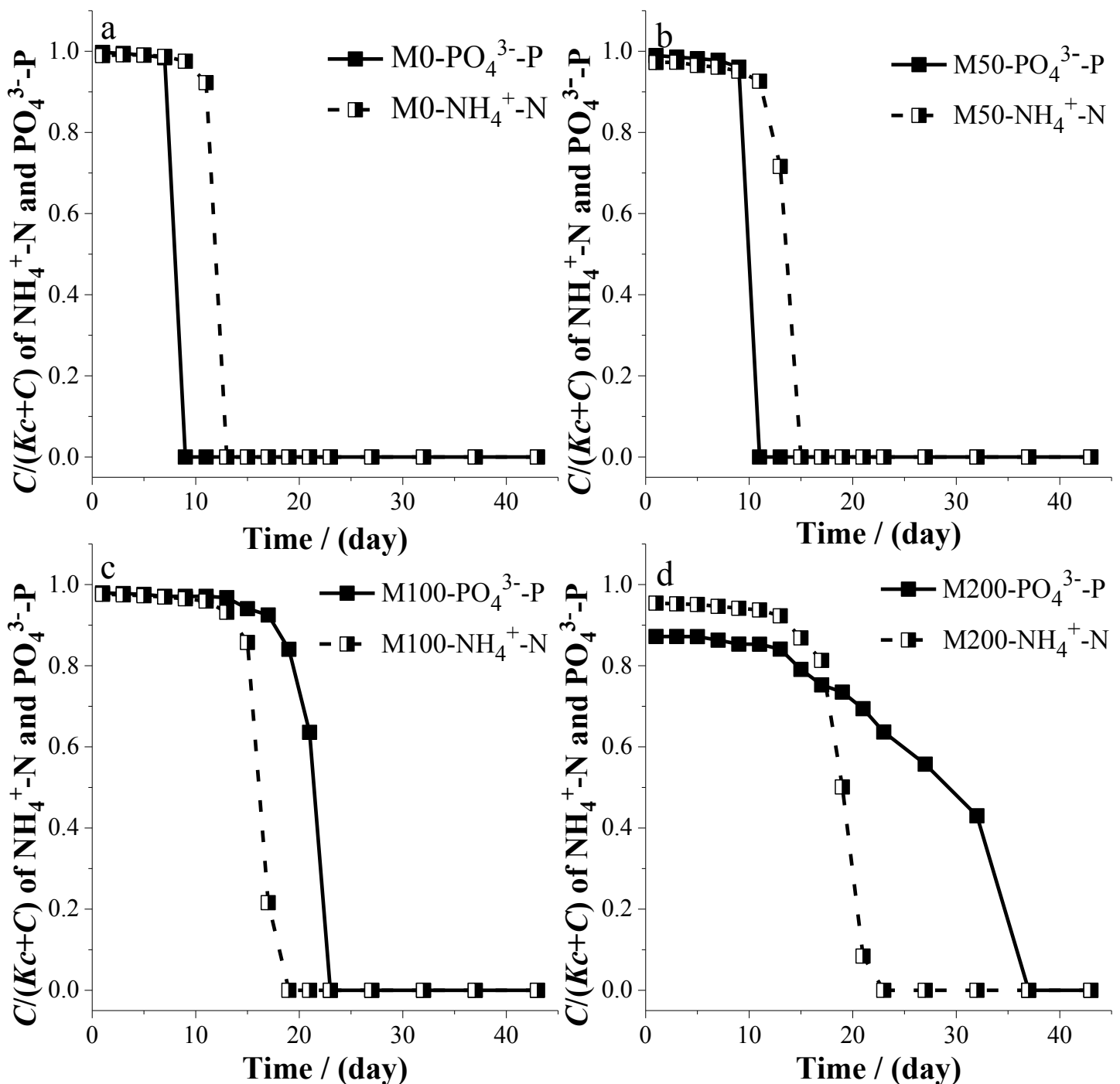

Fig.8 Variations of $\mathrm{C} /(\mathrm{Kc}+\mathrm{C})$ for $\mathrm{NH}_{4}{ }^{+}-\mathrm{N}$ and $\mathrm{PO}_{4}{ }^{3-}-\mathrm{P}$ with time $\left(\mathrm{M} 0,0 \mu \mathrm{g} \cdot \mathrm{L}^{-1}\right.$ prometryn; M50, $50 \mu \mathrm{g} \cdot \mathrm{L}^{-1}$ prometryn; M100, $100 \mu \mathrm{g} \cdot \mathrm{L}^{-1}$ prometryn; M200, 200 $\mu \mathrm{g} \cdot \mathrm{L}^{-1}$ prometryn.) Data shown are average value of two independent measurements.

\section{Conclusions}

Applications of Logistic function alone, Monod function alone and joint application of Monod and Logistic functions were used to study the effect of different prometryn concentrations on $M$. aeruginosa growth in incubator experiments. Logistic function (Eq. 1) gives a good description of the experimental data up to the end of stationary phase of algae growth. The derived formulas for the growth rate (Eq. 2), specific growth rate (Eq. 3) and inhibition rate (Eq. 4a) agree reasonably well to 
the measured data. Our study also provides experimental evidence for supporting the use of Logistic function to reproduce algal nutrients utilization dynamics (Eq. 5), and equation (Eq. 6) to describe the relationship between algae densities and consumed nutrients concentrations is also worked out based on Logistic function.

Application of Monod function (Eq. 8) alone provides a poor prediction of algal growth, while the joint application of Monod and Logistic functions (Eq. 9) produces more accurate relationship between specific growth rates and nutrients concentrations. Inhibitory effects of prometryn on $M$. aeruginosa are observed. In general, the half saturation coefficient, $K_{c}$ for either $\mathrm{PO}_{4}{ }^{3-}-\mathrm{P}$ or $\mathrm{NH}_{4}{ }^{+}-\mathrm{N}$ in Monod function increases with increasing prometryn concentrations.

Prometryn concentrations can cause shifts in limiting nutrients, i.e. $\mathrm{PO}_{4}{ }^{3-}-\mathrm{P}$ or $\mathrm{NH}_{4}{ }^{+}-\mathrm{N}$ or both, for algae growth. The ending time of lag phase or beginning time of exponential phase can be determined by $t_{1}=\frac{a-\ln (5+2 \sqrt{6})}{r}$ and the ending time of exponential phase or beginning time of stationary phase by $t_{3}=\frac{a-\ln (5-2 \sqrt{6})}{r}$.

\section{Acknowledgements}

The study is financially supported by the National Natural Science Foundation of China (11672139), the Natural Science Foundation of Tianjin (18YFZCSF00510 and 15JCYBJC22500, the Fundamental Research Funds for the Central Universities and China-Poland science and technology cooperation committee regular meeting exchange program (37-14).

\section{Author contribution}

S. L. Huang, W. W. Kong and F. F. Shi conceived the research and designed the 
experiments; W. W. Kong, F. F. Shi, Y. B. Feng and Y. Xiao performed the experiments; S. L. Huang and W. W. Kong formulated all equations; S. L. Huang, W. W. Kong, F. F. Shi and Y. B. Feng analyzed the data; W. W. Kong and S. L. Huang wrote the article, S. L. Huang supervised and edited the manuscript. J. G. Zhou polished the English of the first version. All authors read and approved the final manuscript. All authors agree to authorship and submission of the manuscript for peer review.

\section{Conflict of interest statement}

The authors declare no competing financial interests.

\section{Statement of informed consent, human/animal rights}

No conflicts, informed consent, human or animal rights applicable.

\section{References}

[1] Bailley J F, Ollis D F. Biochemical Engineering Funadamentals, 2ndedn. Tata McGraw Hill Publishers, Chennai, 1986: 408-440.

[2] Banks H T, Collins E, Flores K, et al. Statistical error model comparison for logistic growth of green algae (Raphidocelissubcapitata) [J]. Applied Mathematics Letters, 2017, 64:213-222.

[3] Bittencourt-Oliveira M D C, Chia M A, Camargo-Santos D, et al. The effect of saxitoxin and non-saxitoxin extracts of Cylindrospermopsis raciborskii, Cyanobacteria) on cyanobacteria and green microalgae[J]. Journal of Applied Phycology, 2016, 28(1):1-10. 
[4] Cerucci M, Jaligama G K, Ambrose R B J. Comparison of the monod and droop methods for dynamic water quality simulations.[J]. Journal of Environmental Engineering, 2010, 136(10):1009-1019.

[5] Chalifour A, Leblanc A, Sleno L, et al. Sensitivity of Scenedesmus obliquus, and Microcystis aeruginosa, to atrazine: effects of acclimation and mixed cultures, and their removal ability[J]. Ecotoxicology, 2016, 25(10):1-10.

[6] Dortch Q., Thompson P. A., Harrison P. J. Short-term interaction between nitrate and ammonium uptake in Thalassiosira pseudonana : Effect of preconditioning nitrogen source and growth rate[J]. Marine Biology, 1991, 110(2):183-193.

[7] Droop, M. R. Some thoughts on nutrient limitation in algae[J]. J. Phycol, 1973, 9: $264-272$.

[8] Droop, M. R. 25 years of algal growth kinetics[J]. Botanica Marina, 1983, 26: 99-112.

[9] Faust M, Altenburger R, Backhaus T, et al. Predicting thejoint algal toxicity of multi-component s-triazine mixturesat low-effect concentrations of individual toxicants[J]. Aquatic Toxicology, 2001, 56(1): 13-32

[10]García-Fernández J. M., Diez J. Adaptive mechanisms of nitrogen and carbon assimilatory pathways in the marine cyanobacteria Prochlorococcus[J]. Research in microbiology, 2004, 155(10): 795-802.

[11]Glibert P. M., Wilkerson F. P., Dugdale R. C., et al. Pluses and minuses of ammonium and nitrate uptake and assimilation by phytoplankton and implications for productivity and community composition, with emphasis on nitrogen enriched conditions[J]. Limnology \& Oceanography, 2015, 61(4):284-300.

[12]Goudar C T, Joeris K, Konstantinov K B, et al. Logistic equations effectively model Mammalian cell batch and fed-batch kinetics by logically constraining the 
fit.[J]. Biotechnology Progress, 2005, 21(4):1109-1118.

[13]Harrison WG, Harris LR, Irwin BD (1996) The kinetics of nitrogen utilization in the oceanic mixed layer: nitrate and ammonium interactions at nanomolar concentrations[J]. LimnolOceanogr 41:16-32

[14]Healey F P. Slope of the Monod equation as an indicator of advantage in nutrient competition [J]. Microbial Ecology, 1980, 5(4):281-286.

[15]Huang J, Xu Q, Wang X, et al. Evaluation of a Modified Monod Model for Predicting Algal Dynamics in Lake Tai[J]. Water, 2015, 7(7):3626-3642.

[16]Hiddink,J., Kaiser,M., Implications of Liebig's law of the minimum for the useof ecological indicators based on abundance[J]. Ecography.2005,(28): 264-271.

[17]Jin Z P, Luo K, Zhang S, et al. Bioaccumulation and catabolism of prometryne in green algae[J]. Chemosphere, 2012, 87(3):278-284.

[18]Kargi F. Re - interpretation of the logistic equation for batch microbial growth in relation to Monod kinetics[J]. Letters in Applied Microbiology, 2009, 48(4):398-401.

[19]Kayombo S, Mbwette T S, Katima J H, et al. Effects of substrate concentrations on the growth of heterotrophic bacteria and algae in secondary facultative ponds[J]. Water Research, 2003, 37(12):2937-2943.

[20]Khalseh R. Evaluation of different kinetics for bioethanol production with emphasis to analytical solution of substrate equation $[\mathrm{J}]$. Theoretical Foundations of Chemical Engineering, 2016, 50(4):392-397.

[21]Kooijman S.A.L.M., A.O. Hanstveit, H. Oldersma, Parametric analyses of popu-lation growth in bio-assays, Water Research, 1983, 17: 527-538.

[22]Law, T., Zhang, W., Zhao, J., Arhonditsis, G.B.. Structural changes in lake functioning induced from nutrient loading and climate variability[J]. Ecol. Model, 
2009, 220:979-997.

[23]Lee E, Jalalizadeh M, Zhang Q. Growth kinetic models for microalgae cultivation: A review [J]. Algal Research, 2015, 12:497-512.

[24]Lemesle V, Mailleret L. A Mechanistic Investigation of the Algae Growth "Droop" Model[J]. Acta Biotheoretica, 2008, 56(1-2):87-102.

[25]Li Xin, Hu Hong-Ying, Gan Ke, et al. Effects of different nitrogen and phosphorus concentrations on the growth, nutrient uptake, and lipid accumulation of a freshwater microalga Scenedesmus sp. [J]. Bioresource Technology, 2010, 101(14):5494-5500.

[26]Li Yuzhao, Liu Yong, Zhao Lei, et al. Exploring change of internal nutrients cycling in a shallow lake: A dynamic nutrient driven phytoplankton model [J]. Ecological Modelling, 2015, 313:137-148.

[27]Liebig M., Schmidt G., Bontje D., et al. Direct and indirect effects of pollutants on algae and algivorous ciliates in an aquatic indoor microcosm[J]. Aquatic Toxicology, 2008, 88(2): 102-110.

[28]Liu, Y., Evans, M.A., Scavia, D.. Gulf of Mexico hypoxia: exploring increasingsensitivity to nitrogen loads[J]. Environ. Sci. Technol, 2010, 44:5836-5841.

[29]Liu, Y., Scavia, D.. Analysis of the Chesapeake Bay hypoxia regime shift: insights from two simple mechanistic models [J]. Estuar Coast, 2010,33:629-639.

[30] Ma J, Xu L, Wang S, et al. Toxicity of 40 herbicides to the green alga Chlorella vulgaris[J]. Ecotoxicology \& Environmental Safety, 2002, 51(2):128.

[31] Ma J, Wang S, Wang P, et al. Toxicity assessment of 40 herbicides to the green alga Raphidocelis subcapitata[J]. Ecotoxicol Environ Saf, 2006, 63(3):456-462.

[32]Malerba M E, Connolly S R, Heimann K. An experimentally validated nitrate- 
ammonium-phytoplankton model including effects of starvation length and ammonium inhibition on nitrate uptake[J]. Ecological Modelling, 2015, 317:30-40.

[33]Mhadhbi L, Fumega J, Beiras R. Toxicological Effects of Three Polybromodiphenyl Ethers (BDE-47, BDE-99 and BDE-154) on Growth of Marine Algae Isochrysisgalbana [J]. Water Air \& Soil Pollution, 2012, 223(7):4007-4016.

[34]Monod, J. The growth of bacterial cultures[J]. Annu Rev Microbiol, 1949: 8, $371-374$

[35]Murdock J. N., Wetzel D. L. Maromolecular response of individual algal cells to nutrient and atrazine mixtures within biofilms. Microbial Ecology, 2012, 63(4): $761-722$.

[36]Perini,V., Bracken, M.E.S.. Nitrogen availability limits phosphorus uptake inan intertidal macroalga [J]. Oecologia, 2014, 175:667-676.

[37]Pilar Hemandez, Amvrose. Modeling eutrophication Kinetics in Reservoir Microcosms[J].WaterResearch,1997,31:2511-2519.

[38]Powell E Q. Growth rate and generation time of bacteria with special reference to continuous culture[J]. Journal of General Microbiology, 1956, 15 (3):492 511

[39]Qiao Z, Yu H. Effects of stationary phase elongation and initial nitrogen and phosphorus concentrations on the growth and lipid-producing potential of Chlorella sp. HQ.[J]. Journal of Applied Phycology, 2014, 26(1):141-149.

[40]Jones R I, Reynolds C S. The ecology of freshwater phytoplankton[M]. Cambridge University Press, 1984.

[41]Rial D, Murado MA, Menduiña A, Fuciños P, González P, Mirón J, Vázquez J A. Effects of spill-treating agents on growth kinetics of marine microalgae[J]. Journal 
of Hazardous Materials, 2013, 263: 374-381.

[42] Samkhaniyani F, Najafpour G D, Ardestani F. Evaluation of effective nutritional parameters for Scenedesmus, sp. microalgae culturing in a photobioreactor for biodiesel production[J]. International Journal of Environmental Science \& Technology, 2017, 14(5):1-10.

[43] Sergio B, Enrico B, Assimo M, et al. 2013. Raman and SERS study on atrazine, prometryn and simetryntriazine herbicides [J]. Journal of Molecular Structure, 1040: $139-148$

[44] Slegers P M, Leduc S, Wijffels R H, et al. Logistic analysis of algae cultivation[J]. Bioresource Technology, 2015, 179(179):314.

[45] Stemkovski M, Baraldi R, Flores K B, et al. Validation of a Mathematical Model for Green Algae (Raphidocelis Subcapitata) Growth and Implications for a Coupled Dynamical System with Daphnia Magna[J]. Applied Sciences, 2016, $6(5): 155-172$.

[46] Surendhiran D, Vijay M, Sivaprakash B, et al. Kinetic modeling of microalgal growth and lipid synthesis for biodiesel production[J]. Biotech, 2015, $5(5): 663-669$

[47] Sunda W G, Shertzer K W, Hardison. Ammonium uptake and growth models in marine diatoms: Monod and Droop revisited[J]. Marine Ecology Progress, 2009, $386: 29-41$

[48]Tang J. X., Hoagland K. D., Siegfried B. D. Differential toxicity of atrazine to selected freshwater algae[J]. Bulletin of Environmental Contamination Toxicology, 1997, 59(4): 631-637.

[49] Tantanasarit C., Englande A. J., Babel S. Nitrogen, phosphorus and silicon uptake kinetics by marine diatom Chaetoceroscalcitrans, under high nutrient 
concentrations[J]. Journal of Experimental Marine Biology \& Ecology, 2013, 446(5):67-75.

[50]Vörös L., Padisák J. Phytoplankton biomass and chlorophyll-a in some shallow lakes in central Europe[J]. Hydrobiologia, 1991, 215(2): 111-119.

[51]Wang C., X. Wang, R. Su, S. Liang, S. Yang, No detected toxic concentrations inin situ algal growth inhibition tests-A convenient approach to aquatic ecotox-icology, Ecotoxicol[J]. Environ. Saf. 74 (2011) 225-229.

[52]Wang Z, Luo Z, Yan C. Accumulation, transformation, and release of inorganic arsenic by the freshwater cyanobacterium Microcystis aeruginosa.[J]. Environmental Science \& Pollution Research International, 2013, 20(10):7286-7295.

[53] Wang P F, Martin J, Morrison G. Water quality and eutrophicafionin Tampa Bay, Florida[J]. Estuarine, Coastal and Shelf Science,1999,49:1-20.

[54]Wetzel R. G., Likens G.E. Composition and biomass of phytoplanton[J]. Limnological Analyses. Springer New York, USA, 2000.

[55]Wilkinson A D, Collier C J, Flores F, et al. Acute and additivetoxicity of ten photosystem-II herbicides to[24]seagrass [J]. Scientific Reports, 2015, 5: 17443

[56]Wu M., Huang S. L., Zang C. J., et al. Release of nutrient from fish food and effects on Microcystis aeruginosa growth[J]. Aquaculture Research, 2012, 43(10): $1460-1470$.

[57]Wu L, Qiu Z, Zhou Y, et al. Physiological effects of the herbicide glyphosate on the cyanobacterium Microcystis aeruginosa[J]. Aquatic Toxicology, 2016, 178:72.

[58]Xu S, Wang Y, Huang B, Wei Z-B, Miao A-J, Yang L-Y (2015) Nitrogen and phosphorus limitation of phytoplankton growth in different areas of Lake Taihu, China[J]. J Freshw Ecol 30:113-127 
[59]Xu Xiong, Li Chunmei, Sun Jing, Wang Hailiang, Wang Donghong, Song Hanwen, Wang Zijian. Residue Characteristics and Ecological Risk Assessment of Twenty-nine Pesticides in Surface Water of Major River-Basin in China[J]. Asian Journal of Ecotocicology, 2016, 11(2):347-354. (in chinese)

[60]Zeng Q, Qin L, Bao L, et al. Critical nutrient thresholds needed to control eutrophication and synergistic interactions between phosphorus and different nitrogen sources[J]. Environmental Science \& Pollution Research International, 2016, 23(20):1-12

[61]Zhang J, Ni Y, Ding T, et al. The role of humic acid in the toxicity of arsenite to the diatom Navicula sp.[J]. Environmental Science \& Pollution Research, 2014, 21(6):4366-75.

[62]Zhang, P., Zhai, C., Chen, R., Liu, C., Xue, Y., Jiang, J., 2012. The dynamics of the waterbloom-forming Microcystis aeruginosa and its relationship with biotic andabiotic factors in Lake Taihu, China[J]. Ecol. Eng. 47, 274-277.

[63]Zhou J.H., Hu F., Jiao J.G., Liu M.G., Li X.H.. Effects of bacterial-feeding nematodes and prometryne-degrading bacteria on the dissipation of prometryne in contaminated soil[J]. J. Soil. Sediment. 2012,12:576-585.

[64]Zhou B, Bi Y H, Hu Z Y. Effects of temperature on the buoyancy of Microcystis aeruginosa [J]. China Environmental Science, 2014, 34(7):1847-1854. (in Chinese)

[65]Zhu J, He Y, Wang J, et al. Impact of aeration disturbances on endogenous phosphorus fractions and their algae growth potential from malodorous river sediment $[\mathrm{J}]$. Environmental Science \& Pollution Research International, 2017, 24(9):1-9.

[66]Zwietering M. H., I. Jongenburger, F. M. Rombouts, et al. Modeling of the 
Bacterial Growth Curve[J]. Applied and environmental microbiology, 1990, 56(6):1875-1881. 